\title{
Reproductive biology, embryo and early larval morphology, and development rates of krill (Euphausia lamelligera and Euphausia distinguenda), endemic to the Eastern Tropical Pacific
}

\author{
Israel Ambriz-Arreola ${ }^{1,2, *}$, Jaime Gómez-Gutiérrez ${ }^{2}$, \\ María del Carmen Franco-Gordo ${ }^{1}$, Eva R. Kozak ${ }^{1}$
}

${ }^{1}$ Centro de Ecología Costera, Universidad de Guadalajara, Gómez Farias 82, San Patricio Melaque, Jalisco CP 48980, Mexico

${ }^{2}$ Instituto Politécnico Nacional, Centro Interdisciplinario de Ciencias Marinas, Departamento de Plancton y Ecología Marina, Ave. IPN S/N, Col. Playa Palo de Santa Rita, La Paz, Baja California Sur CP 23096, Mexico

\begin{abstract}
The reproductive biology and early life phases of tropical broadcast spawning krill are largely unknown worldwide. This investigation provides the first published data on the reproductive period, brood size, embryo and nauplius-to-metanauplius morphology, biometry, development, and hatching success rates of two of the smallest krill species known (Euphausia lamelligera, $<11 \mathrm{~mm}$ and E. distinguenda, $<14.5 \mathrm{~mm}$ total length), endemic to the Eastern Tropical Pacific. Embryos were obtained from gravid females collected on the Jalisco continental shelf (Mexico) every 2 wk from July 2011 to June 2012, and incubated under laboratory conditions. Both species spawned throughout the year (with higher brood sizes between Jan and Jun), showing similar mean interspecific brood sizes: E. lamelligera, 34 eggs female $^{-1}$ (range: 4-95) and E. distinguenda, 36 eggs female ${ }^{-1}$ (range: 14-72). E. distinguenda spawned larger eggs (chorion 0.700, embryo 0.329 mean diameters, perivitelline space [PVS] $0.185 \mathrm{~mm}$ ) than E. lamelligera (chorion 0.405, embryo 0.291 , PVS $0.057 \mathrm{~mm})$. Both species had high hatching success $(>66 \%)$ with the shortest hatching times (9 to $14 \mathrm{~h}$ ) known so far for any species of the Order Euphausiacea. E. distinguenda was significantly larger than E. lamelligera at each early larval stage. A pseudometanauplius stage (molting between nauplius and metanauplius stages), previously thought to be an exclusive stage of sac-spawning species, was observed for both broadcast spawning species. Our results support the hypothesis that both species exhibit a continuous but seasonally variant spawning reproductive strategy associated with female body size and seasonal coastal upwelling dynamics, and show brood sizes within the low range of variability known for temperate krill species.
\end{abstract}

KEY WORDS: Euphausia lamelligera $\cdot$ Euphausia distinguenda $\cdot$ Embryogenesis $\cdot$ Nauplius · Development times $\cdot$ Reproductive biology $\cdot$ Eastern Tropical Pacific

\section{INTRODUCTION}

Very little is known about the reproductive biology/ ecology of tropical euphausiids (Order Euphausiacea, commonly known as krill), except for their zoogeographic distribution, vertical distribution, seasonal abundance patterns, population structure, and

*Corresponding author: rayamaris@gmail.com sex ratio. This is because relatively little research has been done in low latitude marine ecosystems, as tropical krill are small (not suitable for a fishery), and because it has been long assumed that they occur in low abundance, have low secondary production rates, and do not form dense aggregations like subtropical, temperate, and polar krill species. There-

() The authors 2015. Open Access under Creative Commons by Attribution Licence. Use, distribution and reproduction are unrestricted. Authors and original publication must be credited.

Publisher: Inter-Research · www.int-res.com 
fore, our understanding of their ecological function and contribution to the productivity rates of zooplankton in the tropical food web is still incipient and deserves scientific attention (Wang 1965, Wilson et al. 2003, Ambriz-Arreola et al. 2012). Knowledge is particularly deficient in reproductive strategies, embryology and early larval stage ontogeny and taxonomy for endemic krill species of the Eastern Tropical Pacific (ETP), but their vertical and horizontal distribution and abundance are relatively well known (Valentine \& Ayala 1976, Brinton 1979, Färber-Lorda et al. 1994, 2004, 2010, Fernández-Álamo \& FärberLorda 2006, Ambriz-Arreola et al. 2012).

Fifteen krill species have been recorded in the northern region of the ETP off Mexico (Brinton 1962, 1979, Mundhenke 1969). Five of them are endemic and include two of the smallest and numerically dominant krill species in the ETP region: Euphausia lamelligera ( $<11 \mathrm{~mm}$ total length) and $E$. distinguenda (<14.5 mm total length) (Baker et al. 1990, Brinton et al. 2000, Ambriz-Arreola et al. 2012). E. distinguenda has larger heterozygosity (as a proxy of variability in large outbreeding) than temperate and polar species (Valentine \& Ayala 1976), suggesting a trend of low genetic variability in high latitude species and high genetic variability in low latitude species. High endemism of zooplankton species in the ETP is likely due to long-term evolutionary adaptation and speciation in this region, which features year-round high temperatures, pronounced water column stratification, and a shallow upper boundary of the oxygen minimum zone (caused by regional relatively low horizontal speed current circulation and relatively high surface primary production/respiration rates that deplete oxygen concentrations in deeper waters). It has been proposed that these environmental conditions promote low seasonal variability of zooplankton standing stock and relatively low zooplankton biomass (Fernández-Álamo \& Färber-Lorda 2006). However, so far there have been no estimations of brood size or studies of the reproductive season for any tropical krill species in the ETP.

Recently, it was demonstrated that E. lamelligera and E. distinguenda show strong seasonal and interannual variability of larval (calyptopis and furcilia phases) and postlarval (juvenile and adult phases) abundances associated with upwelling and downwelling coastal variability, suggesting that both species reproduce throughout the year (Ambriz-Arreola et al. 2012). Reproductive biology (gonad development and brood sizes) and spawning periods of both species (as with most broadcast tropical species) have not been studied (Ross \& Quetin 2000). There are relatively few studies than have counted the oocytes inside the carapace or the eggs of sac-spawning tropical species (Mathew 1980, Wilson et al. 2003). The lack of information is partially because the morphology of embryonic and early larval stages nauplii and pseudometanauplii (indicative of recent spawning) have not yet been described in tropical krill species (Gómez-Gutiérrez et al. 2010a). Previous studies suggested a pattern of continuous reproduction for krill species inhabiting the mid-latitudes and equatorial regions, strongly linked to seasonal upwelling cycles and high food availability (Pillar \& Stuart 1988, Ross \& Quetin 2000, Ambriz-Arreola et al. 2012). In the present study, we evaluate the hypothesis that E. lamelligera and E. distinguenda exhibit continuous reproduction, albeit with some variability in spawning intensity associated with seasonal upwelling dynamics from the northern region of the ETP, measuring their monthly mean brood size under laboratory conditions from gravid females collected in the field.

Margaret Knight from the Scripps Institution Oceanography (San Diego, CA, USA) described the morphology of the metanauplius-to-furciliae stages of $E$. lamelligera and E. distinguenda from specimens collected in the field (Brinton et al. 2000). These descriptions require confirmation through identification of eggs spawned by gravid females incubated under laboratory conditions and following their embryonic and early larval development (nauplius-to-metanauplius stages). Mathew $(1971,1975)$ described E. distinguenda calyptopis and furcilia stages from field samples collected in the Indian Sea. However, it is currently well known that previous reports of E. distinguenda in the Red and Indian Seas were actually describing the endemic species E. sibogae (Brinton 1975, Brinton et al. 2000). Because the morphology of embryos (commonly known as 'eggs') and nauplii stages of E. distinguenda and E. lamelligera are unknown, it is not possible to directly infer the reproductive activity in time and space from field zooplankton samples. So far, no attempts have been made to incubate gravid tropical krill females to record brood size, hatching success, and describe biometry and morphology of embryos and early larval stages (Ross \& Quetin 2000). This investigation is a first step toward monitoring those stages from field samples in order to investigate the distribution and seasonal reproductive periods of each species, similar to studies of krill species in other regions of the world (Gómez-Gutiérrez et al. 2005, 2010a, Plourde et al. 2011).

Embryonic development of euphausiids was first described for the North Atlantic krill Meganyc- 
tiphanes norvegica (Sars 1898, Taube 1909, 1915). Cell division from single cell to gastrulation stages of $M$. norvegica was described in unprecedented detail using cell lineage maps with fluorescence staining (Alwes \& Scholtz 2004). As far as we know, the only previous illustrations and brief descriptions from shipboard gravid female incubations are of embryos and early larval stages of the tropical sac-spawning Stylocheiron carinatum (Ponomareva 1969) and the broadcast spawning E. eximia (Knight 1980). Observations of transparent live embryos of $E$. superba (George 1984, George \& Strömberg 1985, Jia et al. 2014), E. pacifica, Thysanoessa spinifera, T. inspinata, Nematoscelis difficilis (Gómez-Gutiérrez 2002, 2003, 2006, Gómez-Gutiérrez et al. 2010a) and N. simplex (Gómez-Gutiérrez \& Robinson 2005, Gómez-Gutiérrez et al. 2010b) have also improved our understanding of embryonic development and hatching success of euphausiids for species with broadcast and sacspawning reproductive strategies. Embryogenesis and internal morphology of early larval stages (metanauplius and calyptopis 1) of the sac-spawning $N$. simplex were recently studied using histological techniques (Montuy-Gómez et al. 2012).

The biometry of eggs was recently revised and updated for all available krill species worldwide by Gómez-Gutiérrez et al. (2010a). These authors reported mean egg diameter measurements of $E$. distinguenda $(0.320 \mathrm{~mm}$ chorion diameter and $0.218 \mathrm{~mm}$ embryo diameter), but they did not report the biometry for each embryonic stage. The biometry of embryonic and early larval stages of E. lamelligera is currently unknown. Study of the temporal and geographical distributions of their eggs may elucidate species preferences for spawning season and location, centers of larval dispersion, and clues about how embryos survive in the ocean (GómezGutiérrez et al. 2010a). Thus, the goals of the present study were to (1) determine the reproductive biology (brood size and spawning season) and (2) define the morphometric differences of E. lamelligera and E. distinguenda embryos to be able to identify them from field samples, and measure their hatching success, (3) describe the early larval stage nauplius (1 and 2) and re-describe the metanauplius stage (for confirmation purposes) to complete the taxonomic description previously known only from metanauplius, calyptopis, and furcilia stages (Brinton et al. 2000), and (4) estimate embryonic and early larval stage development rates of these 2 tropical krill species for comparison with species from other latitudinal and zoogeographic distribution patterns.

\section{MATERIALS AND METHODS}

\section{Collection of euphausiids and spawning experiments}

Gravid females of Euphausia lamelligera and E. distinguenda were collected every 2 wk during a time series of plankton sampling at Bahía de Navidad station, Mexico $\left(19^{\circ} 09^{\prime} 03^{\prime \prime} \mathrm{N}, 104^{\circ} 44^{\prime} 50^{\prime \prime} \mathrm{W}\right)$, located on the continental shelf of the northeastern tropical Pacific Ocean. Ambriz-Arreola et al. (2012) proposed, based on the vertical structure of the water column, that 3 seasonal climatic periods prevail in the Cabo Corrientes region: a mixed period from February to May, typified by well-mixed water column, relatively low temperatures $\left(<24^{\circ} \mathrm{C}\right)$, high salinities $(>34)$, shallow mixed layer depth $(<30 \mathrm{~m})$, and high plankton biomass driven by intense coastal upwelling events (coastal upwelling index, CUI $>100 \mathrm{~m}^{3} \mathrm{~s}^{-1}$ per $100 \mathrm{~m}$ coastline); a stratified period from July to November characterized by strong vertical stratification of the water column, high temperatures $\left(>25^{\circ} \mathrm{C}\right)$, low salinities $(<34)$ (due to the regional rainy season), relatively deep mixed layer depth (>40 $\mathrm{m}$ depth), and low plankton biomass (oligotrophic conditions); and 2 transitional semi-mixed periods; one from mixed-tostratified conditions (June) and another from stratified-to-mixed conditions (December/January).

Twenty zooplankton samples were collected from July 2011 through June 2012 at night ( 05:00 h) from a $6 \mathrm{~m}$ length fiberglass boat. Zooplankton trawls ( $<30 \mathrm{~m}$ depth) were carried out using a net (1 m diameter, $3 \mathrm{~m}$ long, $300 \mu \mathrm{m}$ mesh, with a closed cod end $0.22 \mathrm{~m}$ in diameter and $0.70 \mathrm{~m}$ long) towed at a constant speed $\left(\sim 4 \mathrm{~km} \mathrm{~h}^{-1}\right)$ for $10 \mathrm{~min}$. The zooplankton sample was gently diluted into a 201 insulated container filled with in situ surface seawater and transported (usually within $1 \mathrm{~h}$ ) to the land-based laboratory.

Gravid females of both krill species were visually identified by the presence of intense blue-colored ovaries (see Fig. S1 in the Supplement at www.intres.com/articles/suppl/s001p143_supp.pdf). Active and healthy gravid females were placed individually into $250 \mathrm{ml}$ glass bottles $(8.5 \mathrm{~cm}$ height $\times 6.6 \mathrm{~cm}$ diameter $)$ containing filtered sea surface water $(64 \mu \mathrm{m})$ collected at the sampling station. The specimens were incubated under continuous dark conditions inside a plastic cooler. Incubation temperature was set at $25 \pm$ $1^{\circ} \mathrm{C}$, which represents the average temperature recorded in the upper water column $(<30 \mathrm{~m}$ depth) at the study area. Additional incubations were conducted at temperatures from 22 to $29^{\circ} \mathrm{C}$ to estimate development time ranges in their seasonally chang- 
ing habitat (Ambriz-Arreola et al. 2012). The females usually spawned between 07:00 and 08:00 h $(<2 \mathrm{~h}$ after they were incubated). After each female spawned, the embryos were monitored every $10 \mathrm{~min}$ during the first hour to detect the rapid early embryonic development stages (1 cell to 64 cell multiple stages) and every hour for further embryonic development stages (blastula stage to twitching stage until hatching process). After hatching, the early larval stages were observed every $6 \mathrm{~h}$ (nauplius-to-metanauplius stages). Each spawned female was removed from the incubation bottle to avoid cannibalization of the eggs and to measure its total length (from the forward carapace rim to the tip of the telson, expressed in $\mathrm{mm}$ ), carapace length (CL, from the forward carapace rim to the posterior notch of the carapace), and preserved in $5 \%$ formalin with saturated sodium borate. The spawned eggs were left untouched to avoid altering their embryonic and further larval development rates.

\section{Brood size, biometry, and embryonic development time}

We used the nomenclature of the development stages of embryos after spawning according to previous studies of several broadcast krill species (Ponomareva 1963, Quetin \& Ross 1984, 1989, George \& Strömberg 1985, Gómez-Gutiérrez 2002), distinguishing the following embryonic stages: single cell (SC), multiple cell (MC), early blastula (eB), late blastula (lB), early gastrula (eG), late gastrula (lG), post gastrula (pG), early limb-bud (eLB), late limb-bud (lLB), and twitching (TW) stages. Eggs of each spawning event were counted to measure the females' brood size (number of eggs produced per female per spawning event) and at least 15 live eggs from each brood were photographed (recording the stereoscope magnification zoom for each digital photograph) under an optical microscope (Carl Zeiss, Axiostar Plus) equipped with a calibrated micrometer and a digital AxioCam 1Cc1 camera (Carl Zeiss, with 5x and $10 \times$ magnification zoom) connected to a desktop computer. The chorion and embryo diameters at each embryonic development stage were measured from these scaled color photographs. The embryo is suspended in fluid within the chorion, moving freely and sinking to the bottom side of the shell. Therefore, the perivitelline space (PVS) is not always symmetrical for measurement purposes. Thus, we calculated the PVS as follows (Gómez-Gutiérrez et al. 2010a):

$$
\mathrm{PVS}=\mathrm{CD}-\mathrm{ED} / 2
$$

where $\mathrm{CD}$ is the chorion diameter and ED is the embryo diameter. We used Axiovision v.4.0 software to obtain digital images of each embryo and early larval stage and measure their morphological features. Acquired digital images were post-processed for brightness and contrast using Adobe Photoshop CS5, and Adobe Illustrator CS5 for subsequent image assembling (see Figs. 3-6, Figs. S1 \& S2 in the Supplement). The eggs spawned from each female were transferred into multi-well trays and observed regularly until they developed from the nauplius to metanauplius stage. Embryonic hatching success was estimated as the percentage of embryos that hatched from the brood size of each incubated female.

The average biometric measurements of the embryos (chorion, embryo, and PVS diameters) of E. lamelligera and $E$. distinguenda for each embryonic stage were statistically compared using a MannWhitney $U$-test. The intraspecific and interspecific multiple average comparison of brood size (eggs female $^{-1}$ ) and female total length $(\mathrm{mm})$ among climate periods were tested using Kruskal-Wallis test followed by Tukey's test (Zar 1996). Linear regression analysis was used to determine the relationship between brood size versus female total length and carapace length of the 2 species. All statistical analyses were performed using Statistica v.7.0 (Stat Soft). Embryonic development and hatching time were compared with those observed in other krill species from polar, temperate, and subtropical latitudes to explore interspecific development rate patterns among krill species from different ecosystems, incubated at approximately the average temperature recorded in their natural habitats (Quetin \& Ross 1984, George \& Strömberg 1985, 1989, Gómez-Gutiérrez 2002, 2003, Gómez-Gutiérrez \& Robinson 2005, Montuy-Gómez et al. 2012, Jia et al. 2014).

\section{Early larval stages morphology and development rates}

Digital photographs of live embryos and early larval stages (nauplius to metanauplius) were taken to measure their biometry and development morphology. Embryos and early larvae were observed at least every 30 min during the first day after spawning, and typically every $4 \mathrm{~h}$ the next day while recording time elapsed between spawning and hatching events. Additional pictures of formalin-preserved nauplii-to- 
metanauplii appendages were taken with an inverse microscope (Olympus model CKX41, 10 to 40× magnification) equipped with a digital camera (Evolution model MP, using QCapture-Pro v.6.0 software) and a calibrated micrometer to observe the morphology and biometry of each pair of first and second antennae and the mandible. Appendages were drawn with thin ink pens, copying them from enlarged photographic images using transparent wax paper.

\section{RESULTS}

\section{Brood size of E. lamelligera and E. distinguenda}

A total of 173 gravid female Euphausia lamelligera ( $\mathrm{n}=115)$ and $E$. distinguenda $(\mathrm{n}=58)$ were collected on 20 of 24 sampling days during the bi-weekly time series (July 2011 to June 2012) (Fig. 1a). Brood size ranged from 4 to 95 eggs female ${ }^{-1}$ for E. lamelligera (average $\pm \mathrm{SD}=34 \pm 20$ ) and from 14 to 72 eggs female $^{-1}$ for $E$. distinguenda (36 \pm 13 ). The average brood size of both species was significantly different among the mixed, semi-mixed, and stratified climatic periods (Kruskal-Wallis post hoc test, $\mathrm{p}<0.001$ ). The brood sizes of $E$. lamelligera were significantly higher during the mixed period than during the stratified and semi-mixed periods $(p=0.001)$, whereas $E$. distinguenda brood sizes were higher during the semimixed period than during the mixed and stratified periods ( $p=0.001$; Fig. $1 b)$. These temporal differences suggest a distinct phenology of maximum reproductive activity for each species. Gravid female total length ranged from 6.5 to $10.8 \mathrm{~mm}$ (average $8.4 \mathrm{~mm}$ ) for E. lamelligera and 9.5 to $14.4 \mathrm{~mm}$ (average $11.9 \mathrm{~mm}$ ) for E. distinguenda. Therefore, E. lamelligera can attain first reproduction at about $60 \%$ and E. distinguenda at $66 \%$ of their respective maximum sizes recorded in this study. In concordance with brood sizes, E. lamelligera females were significantly larger during the mixed period than during the semi-mixed and stratified periods (Kruskal-Wallis test, $\mathrm{p}=0.001$ ) (Fig. 1a,c). However, there were no significant differences in average total length of $E$. distinguenda among months or climatic periods (Mann-Whitney $U$-test, p > 0.05) (Fig. 1a,c). Fecundity presented seasonal variability, with brood size increasing with total length, and a significant positive linear relationship was observed in both species, explaining about $45 \%$ of total brood size variability (Fig. 2a, Table 1). Similarly, a significant regression of brood size against carapace length of E. lamelligera and E. distinguenda was found (Fig. 2e, Table 1).

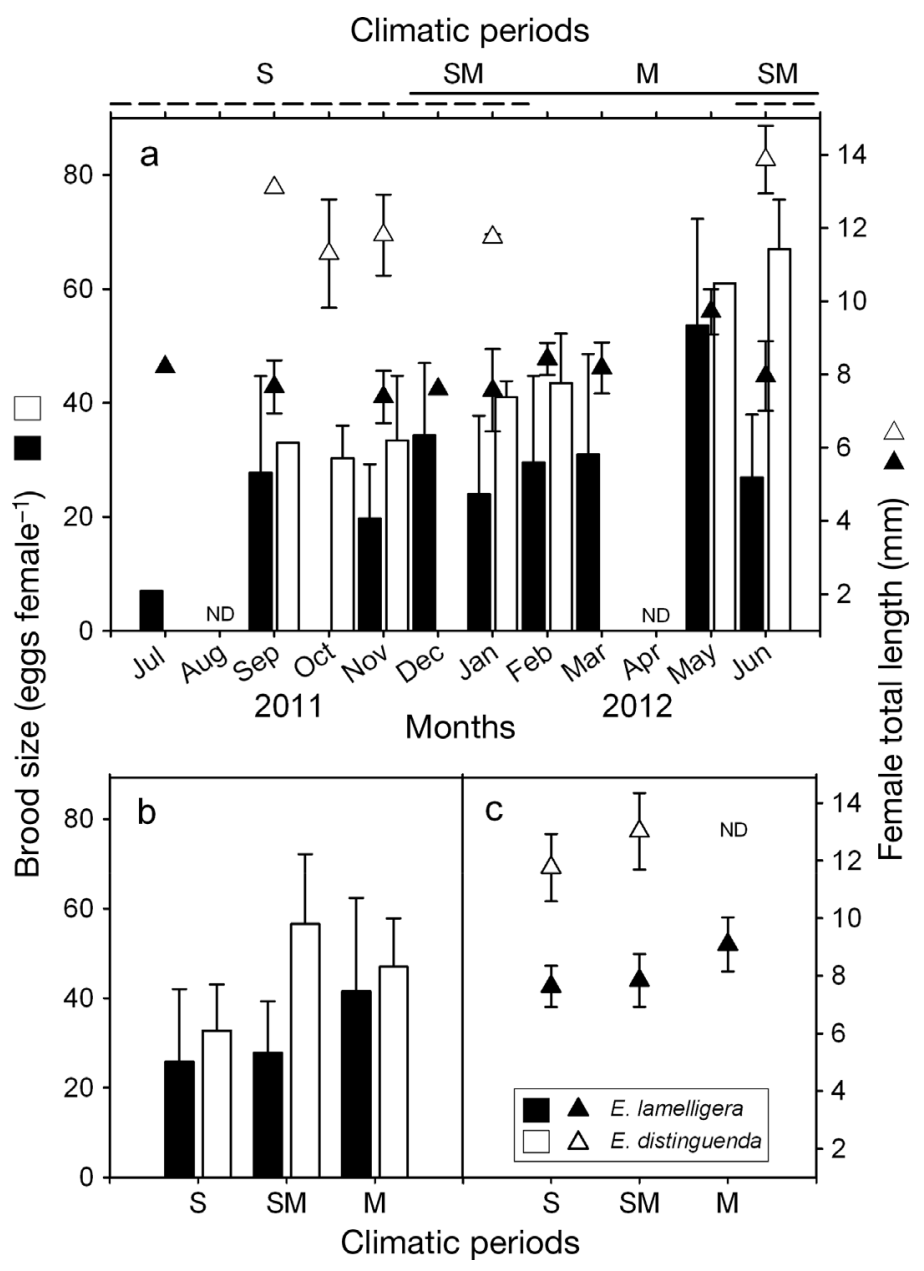

Fig. 1. Brood size (bars) and female total length (triangles) of Euphausia lamelligera $(\mathrm{N}=115)$ and $E$. distinguenda $(\mathrm{N}=58)$, showing (a) monthly mean and standard deviation (SD) of brood size spawned under laboratory conditions (July 2011 to June 2012), (b) brood size and (c) female total length per climatic period as defined in the coastal region off Cabo Corrientes (Ambriz-Arreola et al. 2012). SM = semi-mixed, $\mathrm{M}=$ mixed, $\mathrm{S}=$ stratified, ND = no data

Linear regression indicated that chorion diameter, embryo diameter, and PVS had a significant negative correlation with total length (Fig. 2b-d, Table 1) and carapace size (Fig. 2f-h, Table 1) of E. distinguenda. However, none of these 3 embryonic biometric correlations were significant for E. lamelligera.

\section{Embryo morphology of E. lamelligera and E. distinguenda}

The photographs of all embryonic development stages of E. lamelligera (Fig. 3) and E. distinguenda (Fig. 4) showed similar morphology for both krill species, and also similar to that observed in other broad- 

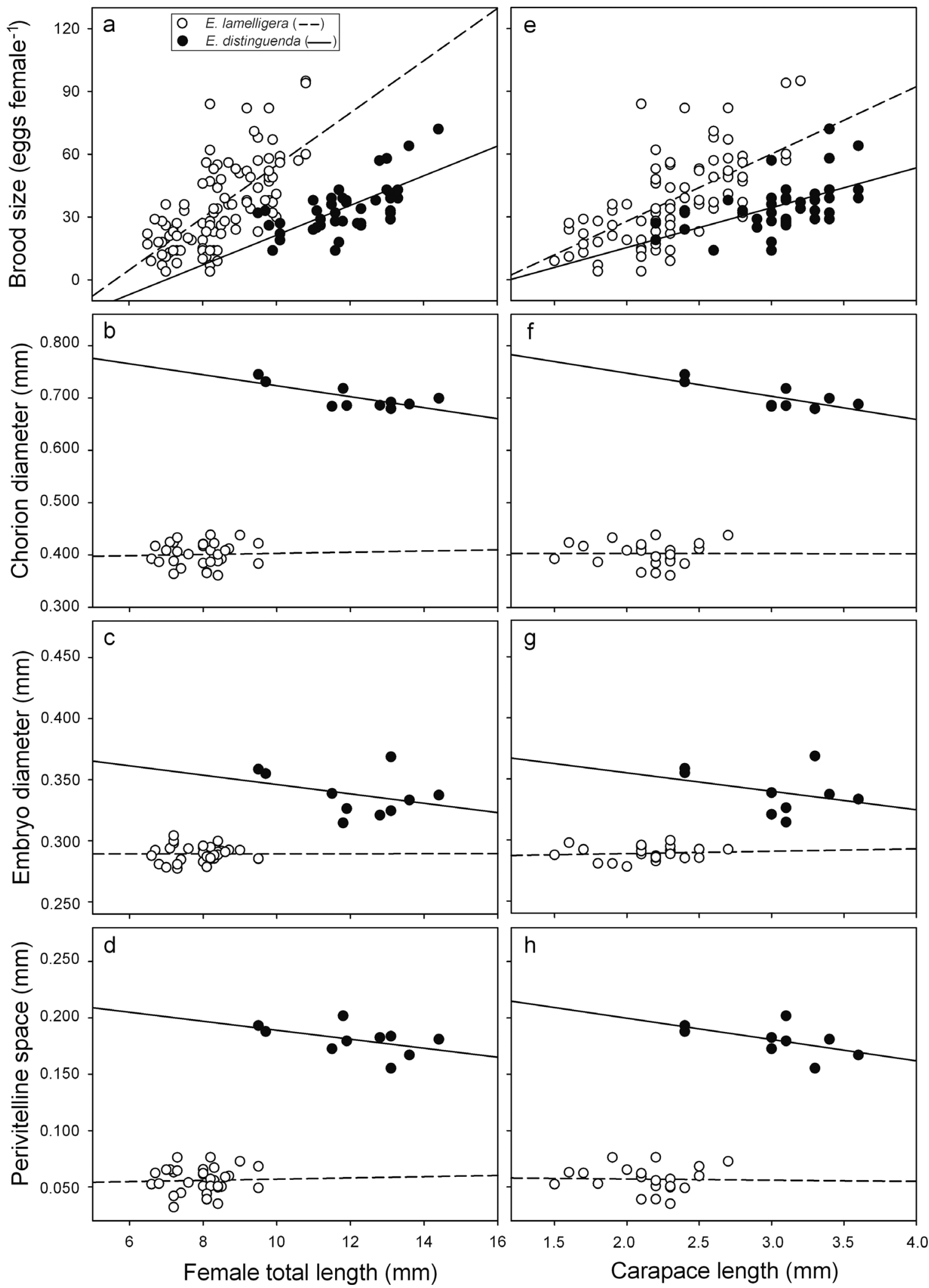

Fig. 2. $(\mathrm{a}, \mathrm{e})$ Brood size, $(\mathrm{b}, \mathrm{f})$ average chorion, $(\mathrm{c}, \mathrm{g})$ embryo diameters, and $(\mathrm{d}, \mathrm{h})$ perivitelline space as a function of female total length $(\mathrm{a}-\mathrm{d})$, and carapace length $(\mathrm{e}-\mathrm{h})$ of Euphausia lamelligera and E. distinguenda collected in the Cabo Corrientes region from July 2011 to June 2012. The equations of the linear regression model are given in Table 1 
Table 1. Linear regression equations of the brood size (BS), chorion diameter (CD), embryo diameter (ED), and perivitelline space (PVS) as a function of total length (TL) and carapace length (CL) of the eggs of Euphausia lamelligera and E. distinguenda females spawned under laboratory conditions

\begin{tabular}{|c|c|c|c|c|c|c|c|c|}
\hline \multirow[t]{2}{*}{ Relationship } & \multicolumn{4}{|c|}{ - Euphausia lamelligera } & \multicolumn{4}{|c|}{ Euphausia distinguenda } \\
\hline & a & $b$ & Adj $\mathrm{r}^{2}$ & $\mathrm{p}$ & $a$ & $b$ & Adj $r^{2}$ & $\mathrm{p}$ \\
\hline BS vs. TL & -70.345 & 12.498 & 0.464 & $<0.001$ & -49.626 & 7.093 & 0.434 & $<0.001$ \\
\hline CD vs. TL & 0.392 & 0.112 & 0.001 & 0.838 & 0.828 & -0.011 & 0.497 & 0.014 \\
\hline ED vs. TL & 0.289 & $<0.001$ & $<0.001$ & 0.988 & 0.384 & -0.004 & 0.010 & 0.328 \\
\hline PVS vs. TL & 0.514 & $<0.001$ & $<0.001$ & 0.843 & 0.229 & -0.003 & 0.139 & 0.156 \\
\hline BS vs. CL & -36.297 & 32.112 & 0.423 & $<0.001$ & -22.706 & 19.028 & 0.247 & $<0.001$ \\
\hline CD vs. $C L$ & 0.403 & -0.001 & $<0.001$ & 0.989 & 0.836 & -0.044 & 0.522 & 0.017 \\
\hline ED vs. CL & 0.285 & 0.002 & $<0.001$ & 0.652 & 0.385 & -0.015 & $<0.001$ & 0.369 \\
\hline PVS vs. CL & 0.059 & -0.001 & $<0.001$ & 0.898 & 0.238 & -0.019 & 0.211 & 0.12 \\
\hline
\end{tabular}

cast spawning species (Taube 1909, 1915, George \& Strömberg 1985, Gómez-Gutiérrez 2002, Alwes \& Scholtz 2004, Gómez-Gutiérrez et al. 2010a, Jia et al. 2014). Therefore, here we only briefly re-describe the stages following the nomenclature of George \& Strömberg (1985) and Jia et al. (2014).

Single cell stage: recently spawned eggs still had the blue coloration of the oocytes from the mature gonad. The embryo developed quickly, taking a spherical shape and homogeneous opaque beige coloration, showing evenly distributed yolk granules. The cytoplasm was accumulated around the nucleus. Two exceedingly thin membranes surrounded the spherical, fertilized, and uncleft zygote; the outer membrane was the fertilization jelly (sensu Jia et al. 2014, also known as jelly coat; Tarling et al. 2009) and the inner membrane was the chorion (also known as embryo membrane; Jia et al. 2014). A third membrane, termed the vitelline membrane, surrounded the dividing zygote (Figs. 3a \& 4a). Both species had a considerably large and transparent PVS that immediately expanded after spawning, and that remained throughout the development to hatching.

Multiple cell stage: the fates of the various cells and cell groups were followed for only the first 5 cleavages because all the early cleavages were holoblastic, leading to easily definable $2,4,8,16$, and 32-cell stages. The first cleavage was meridional (with a slight furrow) and resulted in a 2-cell stage with apparently equally sized cells (Figs. 3b \& 4b). The second cleavage was also meridional, but slightly unequal leading to a 4-cell stage with unequally sized cells. The third cleavage (8-cell stage) was equatorial and unequal resulting in 4 smaller and 4 larger blastomeres. At the fourth cleavage an asynchrony began, with the 4 smaller cells at the animal pole cleaving a little faster than the 4 cells in the vegetative half (16-cell stage). The fifth cleavage leading to the 32-cell stage showed increased asynchrony (Fig. 3d). After the 32cell stage it was difficult to follow the precise pattern of cleavage in living embryos of both species.

Blastula stage: there was a delay in cleavage in 1 or 2 cells at the vegetative pole. The cleavages continued and a clear blastula stage developed with larger cells at the vegetative pole. On the basis of the general cell size, this stage can be divided into an early blastula with big cells (Fig. 3e) and a late blastula with smaller cells (Figs. 3f \& 5c).

Gastrulation: over the subsequent cleavages, gastrulation took place (Figs. $3 g-i \& 4 d, e$ ). During the early phase of gastrulation (Figs. $3 g-h$ \& $4 d$ ) a few large cells were observed migrating into the embryo as well as a blastopore that was only occasionally visible, presumably because of its short duration. During this stage, the mesendoderm was evident. In contrast, the late gastrula stage was characterized by a large number of bigger ectodermal cells, but still with an undifferentiated interior with relatively few cells (Figs. 3i \& 4e).

Early limb-bud stage: the embryos of both species overall still had a spherical shape. In the early limbbud stage the limb primordia were seen; in lateral view they appeared as incipient ridges or, in horizontal view, outlined with lateral invaginations between the 3 pairs of limbs (Figs. $3 \mathrm{j} \& 4 \mathrm{f}$ ). In this stage, the presence of a vitelline membrane surrounding the embryo was still evident. In live embryos, the posterior region of the body showed a reddish coloration (always observed in the same position independent of the nauplius orientation, discarding a possible light artifact of the stereoscope).

Late limb-bud stage: the distal ends of the limbs became free, tubelike structures developing setae on the tip of antenna $1\left(\mathrm{~A}_{1}\right)$, antenna $2\left(\mathrm{~A}_{2}\right)$, and the biramous mandible (Figs. $3 \mathrm{k} \& 4 \mathrm{~g}$ ). The posterior quarter of the body still showed a reddish coloration. At 

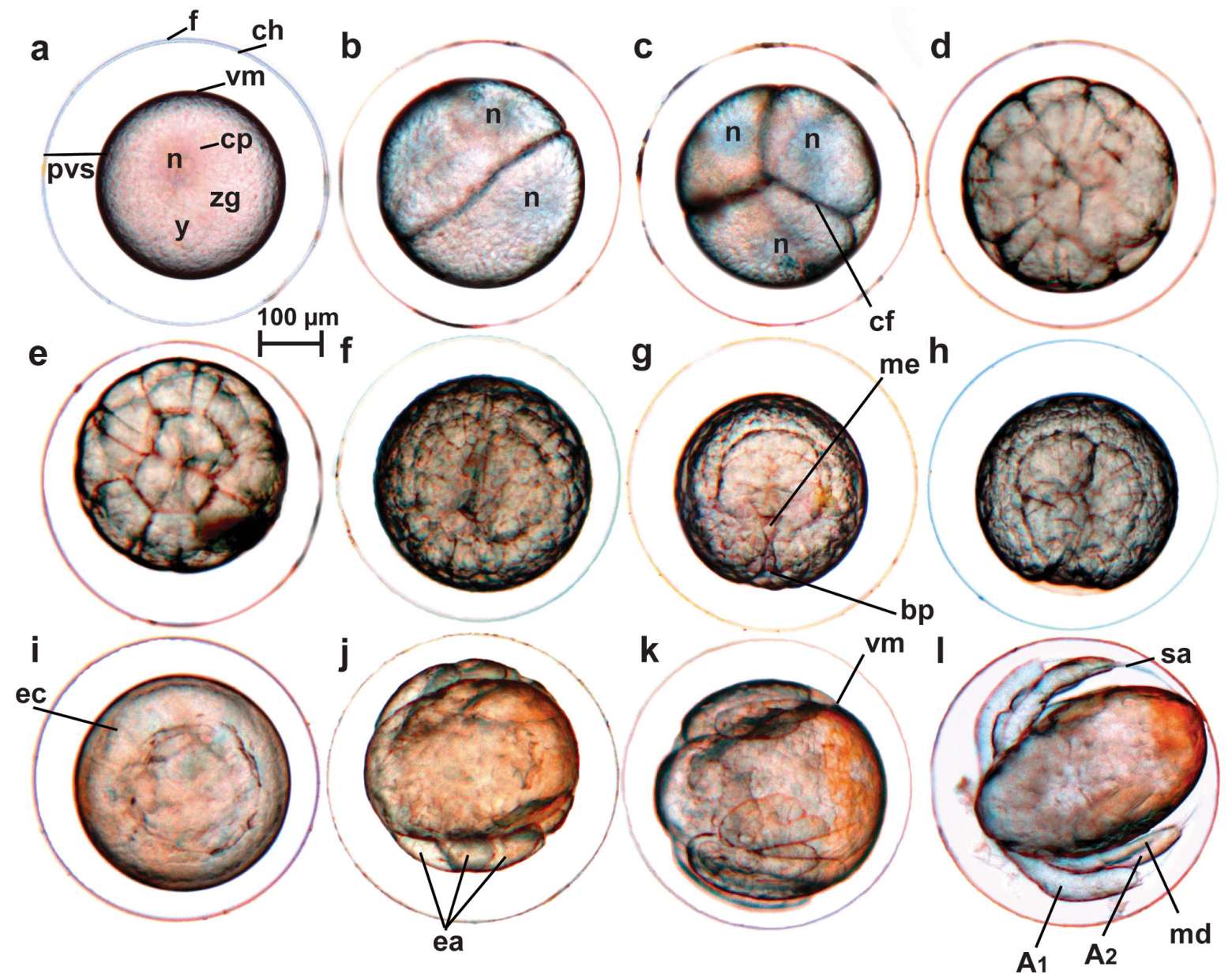

Fig. 3. Embryonic development stages of Euphausia lamelligera: (a) single cell, (b) 2-cells, (c) 4-cells, (d) 32-cells, (e) early blastula, (f) late blastula, (g) early gastrula, (h) late gastrula, (i) post gastrula, (j) early limb-bud, (k) late limb-bud, and (l) twitching stage. Embryo morphology: $\mathrm{f}=$ fertilization jelly, $\mathrm{ch}=$ chorion (also known as embryo membrane), pvs $=$ perivitelline space, $\mathrm{vm}=$ vitelline membrane, $\mathrm{n}=$ nucleus, $\mathrm{cp}=$ cytoplasm, $\mathrm{zg}=$ zygote, $\mathrm{y}=$ yolk, $\mathrm{cf}=$ cross-furrows, $\mathrm{me}=$ mesendoderm, $\mathrm{bp}=$

blastopore, ec = ectodermal cells, ea = early appendages (buds), sa = setae, $\mathrm{A}_{1}=$ antenna $1, \mathrm{~A}_{2}=$ antenna 2 , md = mandible

the late limb-bud stage the mouth was discernible as an invagination, which represented the beginning of the formation of a stomodeum. E. lamelligera embryos were still spherical in shape, but E. distinguenda late limb-bud stage embryos were thinner and oval shaped.

Twitching stage: the last stage before hatching; no vitelline membrane was evident, the muscles of the limbs were differentiated, and the nervous system was already functional (Figs. 31 \& 4h). The posterior half of the body had a reddish coloration, as seen in previous stages. This stage could be recognized by the pulsating heart, as well as the limbs separating from the body prior to the hatching process. Lastly, both species showed an oval shaped nauplius inside the chorion.

\section{Embryo biometry of E. lamelligera and $E$. distinguenda}

We report the biometry of each embryonic and larval development stages because they have relevant taxonomic characteristics for species identifications of specimens collected in the field (Table 2). A Mann-Whitney $U$-test showed interspecific significant differences in morphological biometry of embryos and chorion diameters, and PVS measurements between these 2 krill species throughout the entire embryonic ontogeny ( $\mathrm{p}<0.0001$, Table 3$)$. E. distinguenda embryos had a significantly larger average diameter $(0.700 \pm 0.063 \mathrm{~mm})$, embryo size $(0.329 \pm 0.027 \mathrm{~mm})$, and PVS $(0.185 \pm 0.031 \mathrm{~mm})$ than E. lamelligera diameter $(0.405 \pm 0.026 \mathrm{~mm})$, 

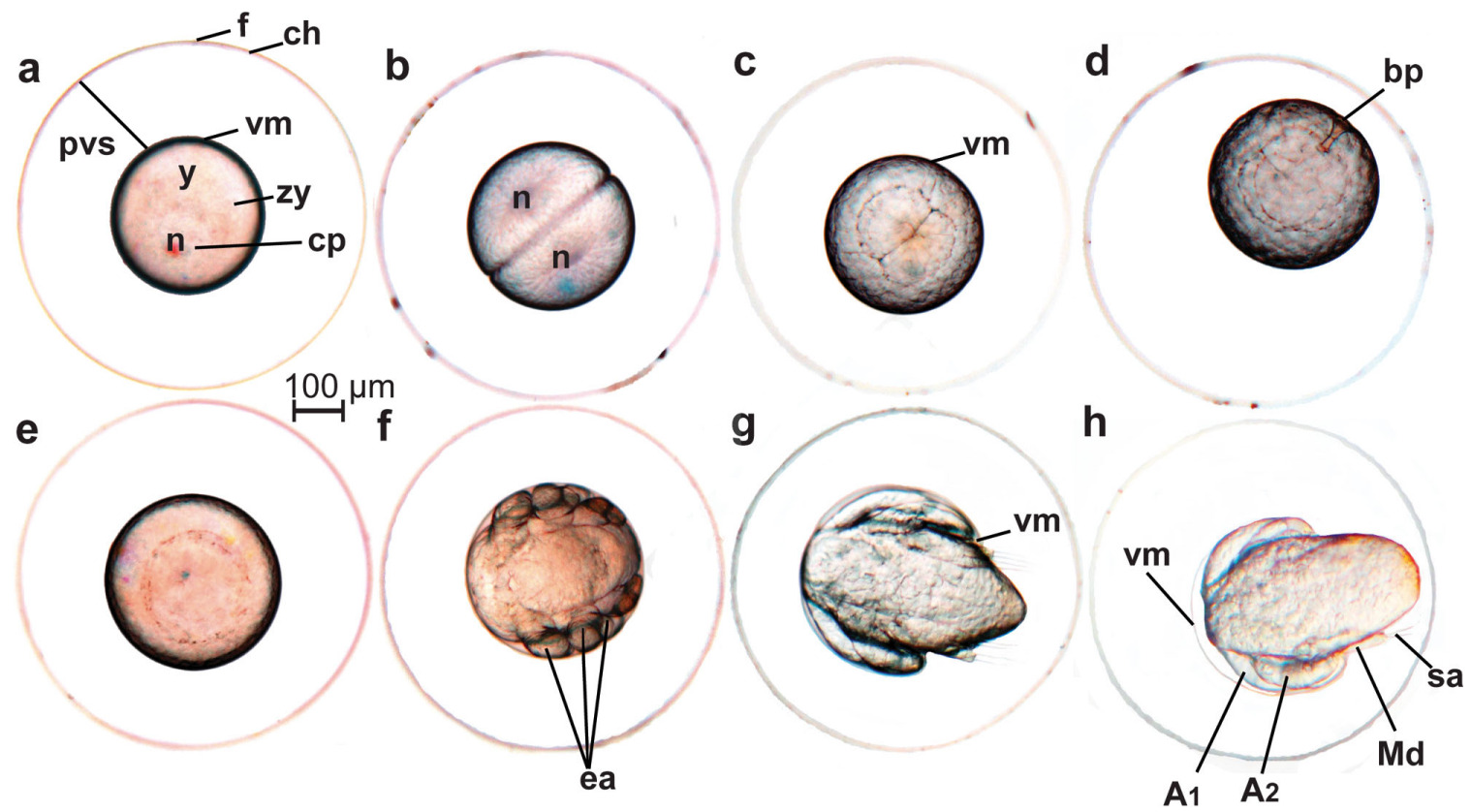

Fig. 4. Embryonic development stages of Euphausia distinguenda: (a) single cell, (b) 2-cells, (c) blastula, (d) gastrula, (e) post gastrula, (f) early limb-bud, (g) late limb-bud, and (h) twitching stage; see Fig. 3 for embryo morphology abbreviations

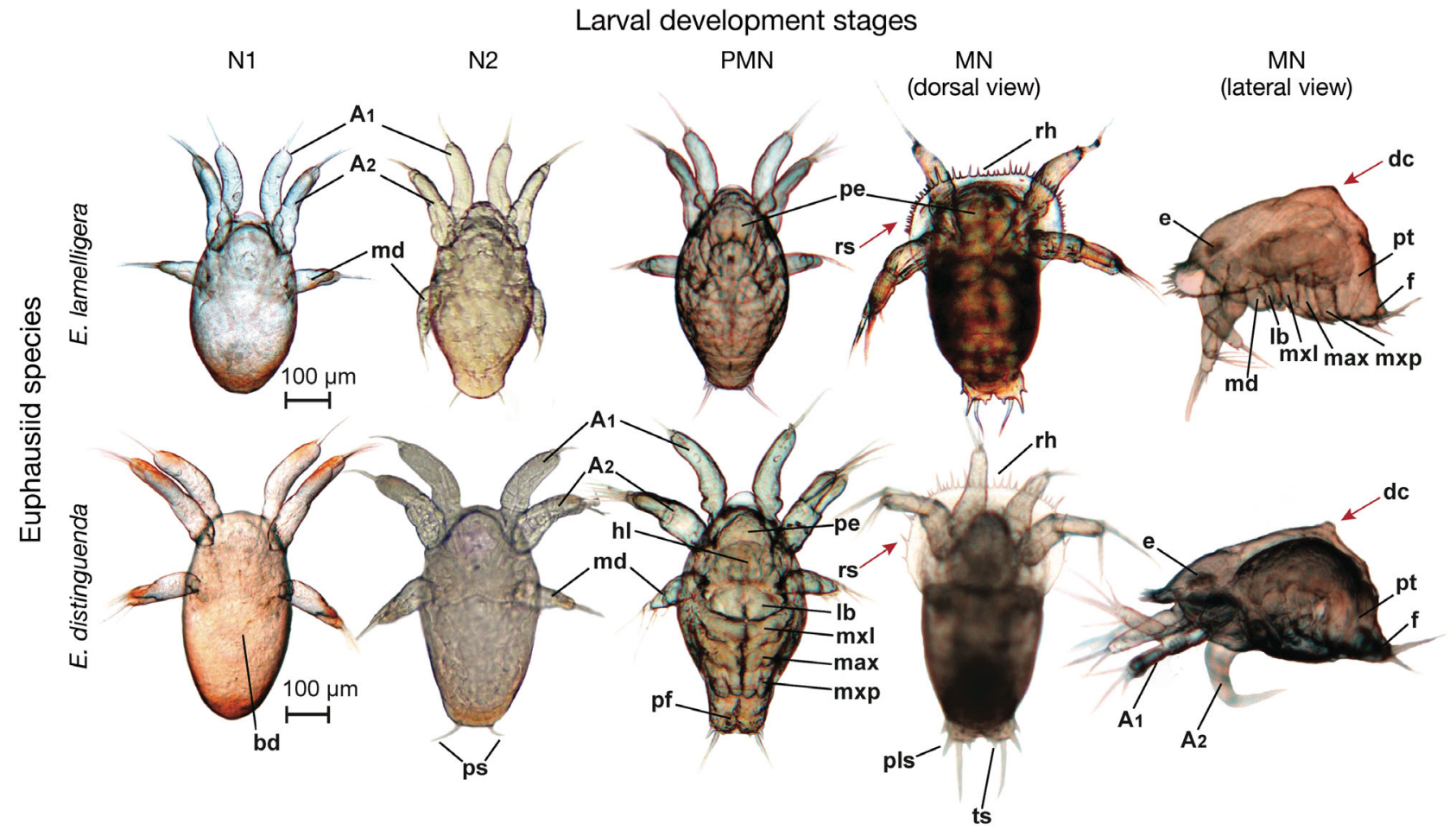

Fig. 5. Euphausia lamelligera and E. distinguenda early larval development stages: N1 = nauplius $1, \mathrm{~N} 2=$ nauplius 2 , PMN = pseudometanauplius, $\mathrm{MN}=$ metanauplius. Early larval morphology: bd = body, $\mathrm{A}_{1}=$ antenna $1, \mathrm{~A}_{2}=$ antenna 2 , md $=$ mandible, $\mathrm{hl}=$ head lobe, $\mathrm{pe}=$ primordial eye, $\mathrm{rs}=$ rostral spines, $\mathrm{lb}=$ labrum, $\max =$ maxilla, $\mathrm{mxl}=$ maxillule, $\mathrm{mxp}=$ maxilliped, pf = primordial furca, ps = posterior spines, pls = posterolateral spines, ts = terminal spines, $\mathrm{rh}=\mathrm{rostral}$ hood, e = eye, $\mathrm{dc}=$ dorsal crest, $\mathrm{pt}=$ primordial trunk, $\mathrm{f}=$ furca 
embryo size $(0.291 \pm 0.011 \mathrm{~mm})$, and PVS $(0.057 \pm$ $0.013 \mathrm{~mm})$ in all embryonic stages $(\mathrm{p}<0.0001$, Table 3). Additionally, E. lamelligera spawned soft, sticky eggs (frequently observed with particles attached, but not attached to each other), with smaller chorion, embryo diameter and PVS than the larger E. distinguenda eggs (hard chorion, nonsticky). These morphological and biometric features of the eggs were useful for ootaxanomic purposes to distinguish the eggs of both species.

Table 2. Biometry of the chorion and embryo diameter, and perivitelline space of the eggs of Euphausia lamelligera and E. distinguenda females spawned under laboratory conditions and reared through early embryonic stages. $\mathrm{SC}=\mathrm{single}$ cell, $\mathrm{MC}=$ multiple cells, eLB = early limb-bud, lLB = late limb-bud, TW = twitching stage, $\mathrm{n}=$ number of measured eggs

\begin{tabular}{|c|c|c|c|c|c|c|c|c|c|c|}
\hline \multirow{2}{*}{$\begin{array}{l}\text { Embryo } \\
\text { development } \\
\text { stage }\end{array}$} & \multirow[b]{2}{*}{$\mathrm{n}$} & \multicolumn{3}{|c|}{ Chorion diameter (mm) } & \multicolumn{3}{|c|}{ Embryo diameter (mm) } & \multicolumn{3}{|c|}{ Perivitelline space (mm) } \\
\hline & & Average & Range & SD & Average & Range & SD & Average & Range & SD \\
\hline \multicolumn{11}{|l|}{ E. lamelligera } \\
\hline $\mathrm{SC}$ & 47 & 0.409 & $0.345-0.515$ & 0.038 & 0.297 & $0.274-0.328$ & 0.015 & 0.056 & $0.034-0.096$ & 0.014 \\
\hline $\mathrm{MC}$ & 68 & 0.411 & $0.355-0.447$ & 0.020 & 0.293 & $0.277-0.310$ & 0.007 & 0.059 & $0.034-0.076$ & 0.009 \\
\hline Blastula & 205 & 0.398 & $0.335-0.453$ & 0.027 & 0.291 & $0.264-0.313$ & 0.008 & 0.053 & $0.025-0.085$ & 0.012 \\
\hline Gastrula & 215 & 0.397 & $0.283-0.440$ & 0.022 & 0.289 & $0.258-0.355$ & 0.010 & 0.054 & $0.021-0-078$ & 0.012 \\
\hline eLB & 120 & 0.413 & $0.339-0.467$ & 0.024 & 0.290 & $0.268-0.320$ & 0.010 & 0.061 & $0.024-0.083$ & 0.012 \\
\hline lLB & 228 & 0.415 & $0.316-0.494$ & 0.027 & 0.290 & $0.257-0316$ & 0.010 & 0.062 & $0.026-0.090$ & 0.013 \\
\hline TW & 84 & 0.399 & $0.339-0.440$ & 0.020 & 0.298 & $0.249-0.338$ & 0.015 & 0.051 & $0.024-0.068$ & 0.009 \\
\hline All & 967 & 0.405 & $0.283-0.515$ & 0.026 & 0.291 & $0.249-0.355$ & 0.011 & 0.057 & $0.021-0.096$ & 0.013 \\
\hline \multicolumn{11}{|c|}{ E. distinguenda } \\
\hline $\mathrm{SC}$ & 82 & 0.706 & $0.513-1.002$ & 0.065 & 0.318 & $0.237-0.337$ & 0.013 & 0.194 & $0.095-0.342$ & 0.030 \\
\hline $\mathrm{MC}$ & 49 & 0.727 & $0.581-0.787$ & 0.046 & 0.320 & $0.235-0.338$ & 0.018 & 0.203 & $0.162-0.233$ & 0.018 \\
\hline Blastula & 36 & 0.723 & $0.602-0.769$ & 0.032 & 0.323 & $0.291-0.321$ & 0.009 & 0.200 & $0.155-0.222$ & 0.015 \\
\hline Gastrula & 40 & 0.680 & $0.534-0.885$ & 0.056 & 0.311 & $0.228-0.366$ & 0.028 & 0.184 & $0.136-0.267$ & 0.024 \\
\hline eLB & 5 & 0.639 & $0.613-0.653$ & 0.017 & 0.328 & $0.317-0.332$ & 0.006 & 0.156 & $0.142-0.161$ & 0.008 \\
\hline lLB & 138 & 0.691 & $0.502-0.992$ & 0.064 & 0.337 & $0.232-0.402$ & 0.022 & 0.177 & $0.070-0.310$ & 0.028 \\
\hline TW & 38 & 0.692 & $0.588-1.015$ & 0.082 & 0.364 & $0.302-0.494$ & 0.040 & 0.164 & $0.082-0.322$ & 0.044 \\
\hline All & 338 & 0.700 & $0.502-1.015$ & 0.063 & 0.329 & $0.228-0.494$ & 0.027 & 0.185 & $0.070-0.342$ & 0.031 \\
\hline
\end{tabular}

Table 3. Mann-Whitney comparison of the interspecific biometry of embryos and early larval stages of Euphausia lamelligera and $E$. distinguenda incubated under laboratory conditions and reared through early embryonic and larval stages. SC $=$ single cell, $\mathrm{MC}=$ multiple cells, eLB = early limb-bud, $\mathrm{LBB}=$ late limb-bud, TW = twitching stage, $\mathrm{N}=$ nauplius, $\mathrm{PMN}=$ pseudometanauplius, $\mathrm{MN}=$ metanauplius

\begin{tabular}{|c|c|c|c|c|c|c|c|c|}
\hline \multirow{2}{*}{$\begin{array}{l}\text { Development } \\
\text { stage }\end{array}$} & \multicolumn{2}{|c|}{ Chorion diameter } & \multicolumn{2}{|c|}{ Embryo diameter } & \multicolumn{2}{|c|}{ Perivitelline space } & \multicolumn{2}{|c|}{ No. of specimens measured } \\
\hline & $Z$-value & $\mathrm{p}$-value & $Z$-value & $\mathrm{p}$-value & $Z$-value & $\mathrm{p}$-value & E. lamelligera & E. distinguenda \\
\hline \multicolumn{9}{|l|}{ Embryos } \\
\hline $\mathrm{SC}$ & -9.426 & $<0.0001$ & -6.338 & $<0.0001$ & -9.425 & $<0.0001$ & 47 & 82 \\
\hline $\mathrm{MC}$ & -9.204 & $<0.0001$ & -8.425 & $<0.0001$ & -9.205 & $<0.0001$ & 68 & 49 \\
\hline Blastula & -9.565 & $<0.0001$ & -9.246 & $<0.0001$ & -9.564 & $<0.0001$ & 205 & 36 \\
\hline Gastrula & -10.039 & $<0.0001$ & -5.601 & $<0.0001$ & -10.038 & $<0.0001$ & 215 & 40 \\
\hline $\mathrm{eLB}$ & -3.780 & 0.0001 & -3.742 & 0.0001 & -3.779 & 0.0001 & 120 & 5 \\
\hline lLB & -16.037 & $<0.0001$ & -15.327 & $<0.0001$ & -15.956 & $<0.0001$ & 228 & 138 \\
\hline \multirow[t]{3}{*}{ TW } & -8.823 & $<0.0001$ & -8.503 & $<0.0001$ & -8.824 & $<0.0001$ & 84 & 38 \\
\hline & \multicolumn{2}{|c|}{ Total length } & \multicolumn{2}{|c|}{ Width } & \multicolumn{2}{|c|}{ Total length/width } & \multicolumn{2}{|c|}{ No. of specimens measured } \\
\hline & $Z$-value & $\mathrm{p}$-value & $Z$-value & $\mathrm{p}$-value & $Z$-value & $\mathrm{p}$-value & E. lamelligera & E. distinguenda \\
\hline \multicolumn{9}{|l|}{ Early larvae } \\
\hline N1 & -12.661 & $<0.0001$ & -0.836 & -0.4032 & -7.111 & $<0.0001$ & 223 & 75 \\
\hline N2 & -11.858 & $<0.0001$ & - & - & - & - & 135 & 159 \\
\hline $\mathrm{PMN}$ & -8.814 & $<0.0001$ & -6.814 & $<0.0001$ & -0.678 & $<0.0001$ & 35 & 154 \\
\hline $\mathrm{MN}$ & -11.691 & $<0.0001$ & -5.790 & $<0.0001$ & -0.615 & 0.539 & 196 & 66 \\
\hline
\end{tabular}




\section{Description of early larval stages of E. lamelligera and E. distinguenda}

The most notable discovery of the present study was the observation of an intermediate larval stage between the nauplius 2 (N2) and metanauplius (MN) stages, here interpreted as a pseudometanauplius (PMN) stage. This is a relevant life cycle observation for these 2 broadcasting species because until now, PMN has been thought to be an exclusive larvae stage for krill species with a sac-spawning reproductive strategy. There is strong evidence that this is a distinct larval stage because the PMN-to-MN molting process was directly observed, and it had significant morphological differences that distinguished it from the N2 and MN stages (see Fig. S2 in the Supplement at www.int-res. com/articles/suppl/s001p143_supp.pdf). Statistical comparison of the interspecific morphological and biometric features of early larval stages (nauplius 1 [N1], N2, PMN, and MN) showed significant stage-dependent differences between both species $(\mathrm{p}<0.0001)$. $E$. lamelligera were smaller and slightly thinner than $E$. distinguenda in all early larval stages (Fig. 5, Tables 3 \& 4), except the N1 stage which did not show significant differences in width between both krill species ( $p>0.05)$. The most prominent morphological characters distinguishing the early larval stages of both species are described below.
Nauplius 1. E. lamelligera N1 had an oval body shape in dorsal view, with an average total length of $0.352 \mathrm{~mm}$ and width of $0.241 \mathrm{~mm}$ (Table 4), with 3 pairs of appendages: $A_{1}$ unsegmented, with 2 terminal long seta and 1 small terminal spine; $A_{2}$, endopod with 2 setae, exopod with 4 setae and 1 terminal small seta; mandible biramous, unsegmented, endopod and exopod each with 3 setae (Figs. 5 \& 6). E. distinguenda N1 was also ovoid in shape, with average total length of $0.422 \mathrm{~mm}$ and average width of $0.243 \mathrm{~mm}$ (Table 4). N1 had 3 pairs of appendages: $\mathrm{A}_{1}$ unseg-

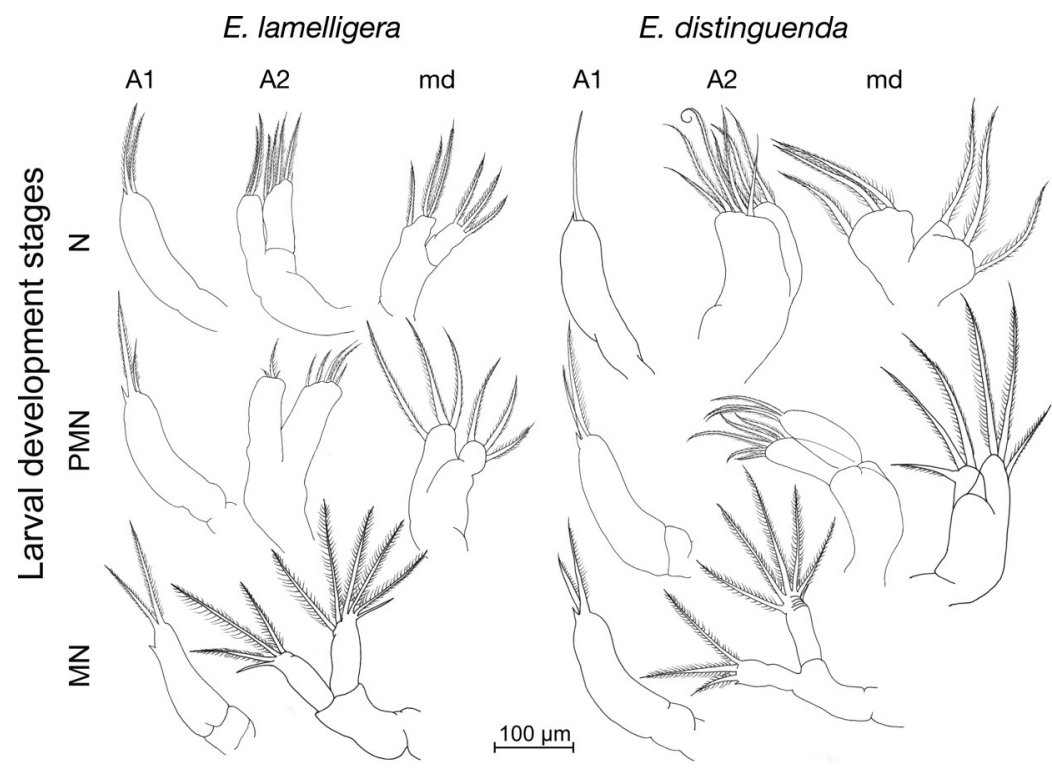

Fig. 6. Swimming appendages of early larval development stages: $(\mathrm{N})$ nauplius, (PMN) pseudometanauplius, and (MN) metanauplius of the tropical krill Euphausia lamelligera and E. distinguenda. $\mathrm{A}_{1}=$ antenna $1, \mathrm{~A}_{2}=$ antenna 2, md $=$ mandible

Table 4. Biometry of body length, width and length/width ratio of the early larval development stages of Euphausia lamelligera and E. distinguenda reared under laboratory conditions. $\mathrm{N}=$ nauplius, $\mathrm{PMN}=$ pseudometanauplius, $\mathrm{MN}=\mathrm{metanauplius}, \mathrm{n}=$ number of measured larvae

\begin{tabular}{|c|c|c|c|c|c|c|c|c|c|c|}
\hline \multirow{2}{*}{$\begin{array}{l}\text { Larval } \\
\text { development stage }\end{array}$} & \multirow[b]{2}{*}{$\mathrm{n}$} & \multirow{2}{*}{$\overline{\text { Average }}$} & \multicolumn{2}{|l|}{ Length $(\mathrm{mm})$} & \multirow[b]{2}{*}{ Average } & \multirow{2}{*}{$\begin{array}{l}\text { Width }(\mathrm{mm}) \\
\text { Range }\end{array}$} & \multirow[b]{2}{*}{ SD } & \multicolumn{3}{|c|}{ — Length/Width $(\mathrm{mm})$} \\
\hline & & & Range & SD & & & & Average & Range & $\mathrm{SD}$ \\
\hline \multicolumn{11}{|l|}{ E. lamelligera } \\
\hline N1 & 223 & 0.352 & $0.296-0.409$ & 0.021 & 0.241 & $0.207-0.301$ & 0.014 & 1.464 & $1.011-1.729$ & 0.110 \\
\hline N2 & 135 & 0.403 & $0.343-0.447$ & 0.020 & 0.254 & $0.228-0.276$ & 0.009 & 1.589 & $1.351-1.725$ & 0.085 \\
\hline $\mathrm{PMN}$ & 35 & 0.401 & $0.376-0.428$ & 0.012 & 0.237 & $0.225-0.251$ & 0.006 & 1.691 & $1.490-1.854$ & 0.064 \\
\hline $\mathrm{MN}$ & 196 & 0.439 & $0.380-0.497$ & 0.020 & 0.239 & $0.200-0.291$ & 0.020 & 1.830 & $1.418-2.242$ & 0.149 \\
\hline \multicolumn{11}{|l|}{ E. distinguenda } \\
\hline N1 & 75 & 0.422 & $0.363-0.467$ & 0.020 & 0.243 & $0.229-0.259$ & 0.008 & 1.788 & $1.679-1.990$ & 0.078 \\
\hline N2 & 159 & 0.451 & $0.365-0.542$ & 0.031 & - & - & - & - & - & - \\
\hline PMN & 154 & 0.469 & $0.378-0.520$ & 0.032 & 0.261 & $0.228-0.296$ & 0.017 & 1.831 & $1.640-2.051$ & 0.010 \\
\hline $\mathrm{MN}$ & 66 & 0.499 & $0.476-0.566$ & 0.022 & 0.266 & $0.239-0.290$ & 0.015 & 1.861 & $1.686-2.083$ & 0.112 \\
\hline
\end{tabular}


mented, with 1 terminal long seta and 1 small terminal spine; $\mathrm{A}_{2}$, endopod with 5 setae, exopod with 3 setae; mandible biramous, unsegmented, endopod and exopod each with 3 setae (Figs. 5 \& 6). Overall, E. distinguenda had a longer body length N1 than E. lamelligera. Both species were distinguishable in the N1 stage because $E$. lamelligera had 2 setae in the antenna and $E$. distinguenda had only one; and because $E$. lamelligera had a total length:width ratio of 1.46 versus 1.79 for E. distinguenda.

Nauplius 2. E. lamelligera N2 had a slightly longer body length in comparison with N1, armed with 1 pair of spines located at the posterior margin of the body. Average total length was $0.401 \mathrm{~mm}$ and width was $0.254 \mathrm{~mm}$ (Table 4), with 3 pairs of appendages (Fig. 5).

E. distinguenda had an ovoid shape and was longer than N1, with an average total length of $0.451 \mathrm{~mm}$, but similar in width (Table 4). It presented 3 pairs of appendages (Fig. 5). As in N1, both species were distinguished in N2 by E. lamelligera having 2 setae in the antenna whereas E. distinguenda had only one.

Pseudometanauplius. E. lamelligera PMN had an elongated oval shape in dorsal view, partially due to the formation of a primordial furca, approximately 2 times longer than its width (Table 4). The posterior margin was armed with 4 pairs of spines: one pair of small posterolateral (outer) spines, one pair of relatively large third spines, and 2 pairs of small rudimentary medial terminal spines. Three pairs of appendages were present: $A_{1}$ and mandible as in N1 and $\mathrm{N} 2$, and $\mathrm{A}_{2}$; the endopod of $\mathrm{A}_{2}$ was armed with 3 setae and the exopod with 5 setae (Figs. $5 \& 6$ ).

E. distinguenda PMN had a pear shaped body, with an oval-shaped head region and elongated posterior extension of the body with 2 posterolateral pairs of spines and one pair of small to rudimentary medial terminal spines. Average total length was $0.469 \mathrm{~mm}$ and width was $0.261 \mathrm{~mm}$ (Table 4). PMN had 3 pairs of appendages: $A_{1}$ was unsegmented, with 2 terminal long setas and 1 small terminal spine, and $\mathrm{A}_{2}$ and mandible morphology were similar to $\mathrm{N} 1$ and $\mathrm{N} 2$ (Figs. 5 \& 6). E. distinguenda had considerably larger PMN than E. lamelligera but no difference in the number of setae in their appendages.

In the PMN stage, both species were already developing a primordial eye, a prominent head lobe, and rudimentary labrum, maxillule, maxilla, and biramous maxilliped that distinguished them from the N2 stage. They lacked the rostral carapace hood fringed with spines typical of the MN stage (Fig. 6).

Metanauplius. E. lamelligera $\mathrm{MN}$ had an average total length of $0.439 \mathrm{~mm}$ and width of $0.239 \mathrm{~mm}$
(Table 4). $\mathrm{A}_{1}$ was unsegmented, with 2 long terminal setae and 1 small subterminal spine. $\mathrm{A}_{2}$ had an endopod with 4 setae; an exopod with 5 long setae and one terminal seta, and reduced mandible (Figs. 5 \& 6). The rostral hood of the carapace was fringed with small marginal rostral spines with larger rostral spines interspersed on the frontal margin and one small pointed dorsal crest without spines. The telson had 2 small pairs of posterolateral spines and 2 pairs of telson spines; the outer pair of telson spines were considerably longer and articulated with the telson (Fig. 5).

E. distinguenda $\mathrm{MN}$ had an average total length of $0.499 \mathrm{~mm}$ and width of $0.266 \mathrm{~mm}$ (Table 4). $\mathrm{A}_{1}$ was similar to PMN stage; $\mathrm{A}_{2}$ with endopod bearing 3 setae and 1 subterminal seta; the exopod had 5 long setae and one terminal seta, and the mandible was reduced (Fig. 6). The rostral carapace hood was fringed with strong spines interspersed with smaller spines, and had a very distinctive dorsal crest without spines. The telson was short, as described in E. lamelligera (Fig. 6).

The MN stage of both species showed prominent development of a pigmented eye, and the labrum, maxilla, maxillule, and a biramous maxilliped were longer than in the PMN stage. Inside the MN hump a primordial trunk was developing, and in the posterior tip a furcal development was already present (Fig. 5).

E. distinguenda MN was larger, wider and had a higher length/width ratio than E. lamelligera. They also had a distinct number of setae in the antenna, and different spinal arrangements on the carapace, which were morphological features of taxonomic value: E. lamelligera had a carapace fringed with small marginal spines with larger spines interspersed on the frontal margin; in contrast, E. distinguenda had a carapace fringed with prominent spines spaced around the margin of the frontal hood and with smaller spines interspersed. Finally, they had distinct dorsal keels; E. lamelligera had a small pointed crest while E. distinguenda had a prominent dorsal keel.

\section{Development times of E. lamelligera and $E$. distinguenda}

These 2 small tropical krill species presented a rapid embryonic development with an average hatching time of $12 \mathrm{~h}\left(25^{\circ} \mathrm{C}\right)$ after spawning (range 9 to $14 \mathrm{~h}$ at 29 to $22^{\circ} \mathrm{C}$ ) (Table 5). The duration of the development time among embryonic and early larval stages was similar in both species. For example, both species had similar average development times to reach the blastula $(\sim 2 \mathrm{~h})$, eLB $(5 \mathrm{~h})$, and TW stages (11 h) 
Table 5. Mean development time (at $25^{\circ} \mathrm{C}$ ) and range (at 22 to $29^{\circ} \mathrm{C}$ ) of the embryos and early larval stages after spawning of Euphausia lamelligera and E. distinguenda incubated under laboratory conditions. $\mathrm{SC}=$ single cell, $\mathrm{MC}=\mathrm{multiple}$ cells, eLB = early limb-bud, lLB = late limb-bud, TW = twitching stages; $\mathrm{N}=$ nauplius, $\mathrm{PMN}=$ pseudometanauplius, $\mathrm{MN}=$ metanauplius.

$$
\mathrm{N}=\text { total number of gravid females, } \mathrm{n}=\text { number of specimens measured }
$$

\begin{tabular}{|c|c|c|c|c|c|c|c|c|}
\hline \multirow{2}{*}{$\begin{array}{l}\text { Development } \\
\text { stage }\end{array}$} & \multicolumn{4}{|c|}{ Euphausia lamelligera $(\mathrm{N}=110)$} & \multicolumn{4}{|c|}{-Euphausia distinguenda $(\mathrm{N}=58)$} \\
\hline & $\mathrm{n}$ & Average time (h) & $\mathrm{SD}$ & Range & $\mathrm{n}$ & Average time (h) & $\mathrm{SD}$ & Range \\
\hline \multicolumn{9}{|l|}{ Embryos } \\
\hline $\mathrm{SC}$ & 4 & 0.00 & - & - & 5 & 0.00 & - & - \\
\hline $\mathrm{MC}$ & 8 & 0.45 & 0.33 & $0.30-1.44$ & 3 & 1.45 & 0.05 & $0.39-1.49$ \\
\hline Blastula & 13 & 1.77 & 0.45 & $1.21-2.30$ & 3 & 2.23 & 0.42 & $1.47-2.44$ \\
\hline Gastrula & 19 & 2.91 & 1.10 & $1.32-5.51$ & 5 & 4.02 & 0.64 & $2.27-3.12$ \\
\hline \multicolumn{9}{|l|}{ Early larvae } \\
\hline $\mathrm{eLB}$ & 13 & 5.32 & 0.94 & $3.33-6.21$ & 2 & 5.26 & 0.43 & $5.32-6.10$ \\
\hline lLB & 15 & 8.84 & 1.22 & $5.53-9.40$ & 9 & 8.13 & 0.91 & $7.32-10.34$ \\
\hline TW & 8 & 10.85 & 0.53 & $9.07-11.02$ & 5 & 10.22 & 1.02 & $9.45-12.47$ \\
\hline N1 & 15 & 11.93 & 1.63 & $9.37-14.26$ & 7 & 12.29 & 0.70 & $10.10-13.18$ \\
\hline N2 & 8 & 16.60 & 4.31 & $14.38-25.41$ & 9 & 18.09 & 3.39 & $16.08-27.31$ \\
\hline $\mathrm{PMN}$ & 2 & 20.14 & 1.13 & $19.53-27.19$ & 6 & 26.68 & 2.70 & $23.05-29.11$ \\
\hline $\mathrm{MN}$ & 5 & 29.30 & 2.32 & $22.40-32.48$ & 4 & 29.51 & 1.69 & $28.07-34.28$ \\
\hline
\end{tabular}

after spawning; and $\sim 12,18,24$, and $30 \mathrm{~h}$ for N1, N2, PMN, and MN, respectively (Table 5). In both species the diameter of the embryo increased throughout embryonic development until the twitching stage (Figs. 3a-l \& 4a-h, Table 2), when the embryo typically hatched. N1 was observed hatching exclusively using the backward hatching mechanism (GómezGutiérrez 2002), with hatching process duration shorter for E. lamelligera ( $<2 \mathrm{~min})$ than for E. distinguenda $(<30 \mathrm{~min})$. Hatching success was consistently high throughout the year for both tropical species: eggs spawned by 12 female E. lamelligera had an average hatching success of $90 \%$ (range: 77 to $100 \%$ ), whereas eggs spawned from 25 E. distinguenda females had an average of $91 \%$, ranging from 66 to $100 \%$.

\section{DISCUSSION}

To the best of our knowledge, this is the first study to report brood size and give a complete description and biometry of embryonic and early larval naupliusto-metanauplius development stages, ontogenetic stage duration, and hatching success of any broadcast tropical krill species in the Order Euphausiacea. We successfully incubated two of the smallest broadcast spawning krill species in the world (Euphausia lamelligera, $<11 \mathrm{~mm}$ and $E$. distinguenda, $<14.5 \mathrm{~mm}$ total length) and explored patterns in the seasonal variability of their brood sizes, concluding that both species reproduce throughout the year although with distinct seasonal peaks in mean brood sizes.

\section{Reproductive seasonal pattern and embryo bio- metry of tropical broadcast spawning krill species}

Ambriz-Arreola et al. (2012) suggested that E. lamelligera and $E$. distinguenda reproduce yearround because calyptopis larval abundances numerically dominated the krill populations off the Cabo Corrientes region based on monthly sampling during 1996 to 1998. The continuous presence of gravid females and brood size observations of both tropical species in this northern region of the ETP confirm the continuous reproduction strategy of both species, although with distinct interspecific maximum reproduction rates among climatic periods (Fig. 1a). We detected the maximum brood size of E. lamelligera during the mixed period (February to May), and of E. distinguenda during the semi-mixed periods (June and December/January), both having a statistically significant linear association of brood size with female total length and carapace length (Figs. 1a-c \& $2 \mathrm{a}, \mathrm{e})$, as has been commonly reported for subtropical sac-spawning species (Wilson et al. 2003, GómezGutiérrez \& Robinson 2005, Gómez-Gutiérrez et al. $2010 b, 2012)$. Interestingly, in polar (E. superba) and temperate (E. pacifica and Thysanoessa spinifera) broadcast spawning krill species, a typical dome shape association of brood size versus total length was recorded (Nicol et al. 1995, Gómez-Gutiérrez et al. 2006, Feinberg et al. 2007, 2013), with older females decreasing brood size after reaching their maximum reproductive activity, even with a larger body size (and carapace volume). In these relatively large krill species with lifespans ranging from 2 to 
$7 \mathrm{yr}$, oogenesis should metabolically decrease with female age. Because E. distinguenda and E. lamelligera are among the smallest broadcast spawning krill species in the world, we presume they have shorter life span (likely <1 yr) than subtropical, temperate, and polar species, due to the relatively high temperatures that prevail in the ecosystem they inhabit. As a result of this shorter life span, tropical krill do not appear to reach a body size and age where females decrease their reproductive effort. However, brood size is not only influenced by female size; food availability seems to affect spawning patterns as well, which is related to the occurrence of intense upwelling events that promote relatively high chlorophyll a (chl a) concentrations and primary productivity during the mixed and semi-mixed climatic periods at Cabo Corrientes (Cepeda-Morales et al. 2009, López-Sandoval et al. 2009a,b, Ambriz-Arreola et al. 2012). Both species spawned smaller brood sizes during the stratified season. In Cabo Corrientes, AmbrizArreola et al. (2012) demonstrated that healthy $E$. lamelligera and E. distinguenda had a high hepatosomatic index (i.e. the proportion of the size of the hepatopancreas and the cephalothorax; this proxy helps to infer body conditions and recent trophic conditions) during the most productive mixed and semimixed periods. High chl a concentrations would provide energy to produce eggs with higher lipid content for embryonic development, and relatively high temperatures would increase growth and development rates of early larval stages compared with those species inhabiting higher latitudes. This evidence confirms that although both species can spawn in any season of the year, their maximum brood sizes overall occurred during periods of high chl a concentrations (mixed and semi-mixed periods), suggesting that seasonality plays a primary role in the magnitude of the female reproductive life history (size, brood size, embryonic and larval development) of $E$. lamelligera and E. distinguenda in the northern region of the ETP.

Even though both species have among the smallest mean brood sizes currently known for broadcast species of the Order Euphausiacea, continuous reproduction, fast ontogenetic development, and a presumed lifespan of $<1$ yr (as seen in the subtropical species Nyctiphanes simplex; Lavaniegos 1992) compensate for their relatively low brood sizes per spawning event. The interbrood period of these tropical species is still unknown, but it is probably shorter than in temperate broadcast spawning species. In $E$. lucens from the Benguela Current System and E. pacifica from the California Current System, spawn- ing occurs every 3 to $7 \mathrm{~d}$ for several months (Stuart 1992, Feinberg et al. 2007), and as it is well known that high temperatures increase metabolic rates, we can reasonably assume that the mean interbrood periods of both tropical species is $3 \mathrm{~d}$ (range 2 to $4 \mathrm{~d}$ ). Precise estimations of egg production rates require further direct observations of interbrood periods and the number of consecutive spawns a female can produce in its lifespan in order to estimate total fecundity. The mean brood size of E. lamelligera (33 eggs female $^{-1}$, range 3 to $96, \mathrm{n}=115$ ) and $E$. distinguenda (36 eggs female ${ }^{-1}$, range 15 to $72, \mathrm{n}=58$ ) can be considered relatively low in comparison with krill species of higher latitudes (Nicol et al. 1995, Feinberg et al. 2007, Gómez-Gutiérrez et al. 2007).

An interspecific comparison of mean chorion and embryo diameter as a function of female total length showed that E. lamelligera and E. distinguenda are among the smallest gravid females in the world (Fig. 7), having some of the smallest eggs and mean brood sizes compared to the other 24 broadcast spawning species (Brinton et al. 2000, GómezGutiérrez et al. 2010a). The chorion and embryo diameters measured for E. lamelligera (0.405 and $0.291 \mathrm{~mm}$, respectively) were a size near the predictive linear regression model (see Fig. 7). In contrast, E. distinguenda (chorion diameter $=0.700$, embryo diameter $=0.329 \mathrm{~mm}$ ) spawned eggs with a chorion diameter in proportion to its total length, well above the average predicted for the rest of the broadcast spawning species (Fig. 7a). The ecological or adaptive value of having a very large PVS is unknown. However, Timofeev et al. (2004) pointed out that a large PVS is a protective feature for embryos developing under unfavorable environmental conditions. Because our krill collections came from a relatively small coastal region within the distribution range of both krill species, the PVS could vary more spatiotemporally than that which was observed in the present study, considering that these species seasonally invade northern latitudes along the west coast of the Baja California peninsula and Gulf of California (Brinton \& Townsend 1980, Lavaniegos et al. 1989).

\section{Description of embryonic and early larval stages of tropical krill species}

The taxonomic description of the metanauplius, calyptopis, and larval furcilia stages of E. lamelligera and $E$. distinguenda was previously reported from specimens directly collected in the field (Brinton et al. 2000). We confirmed that the morphological descrip- 

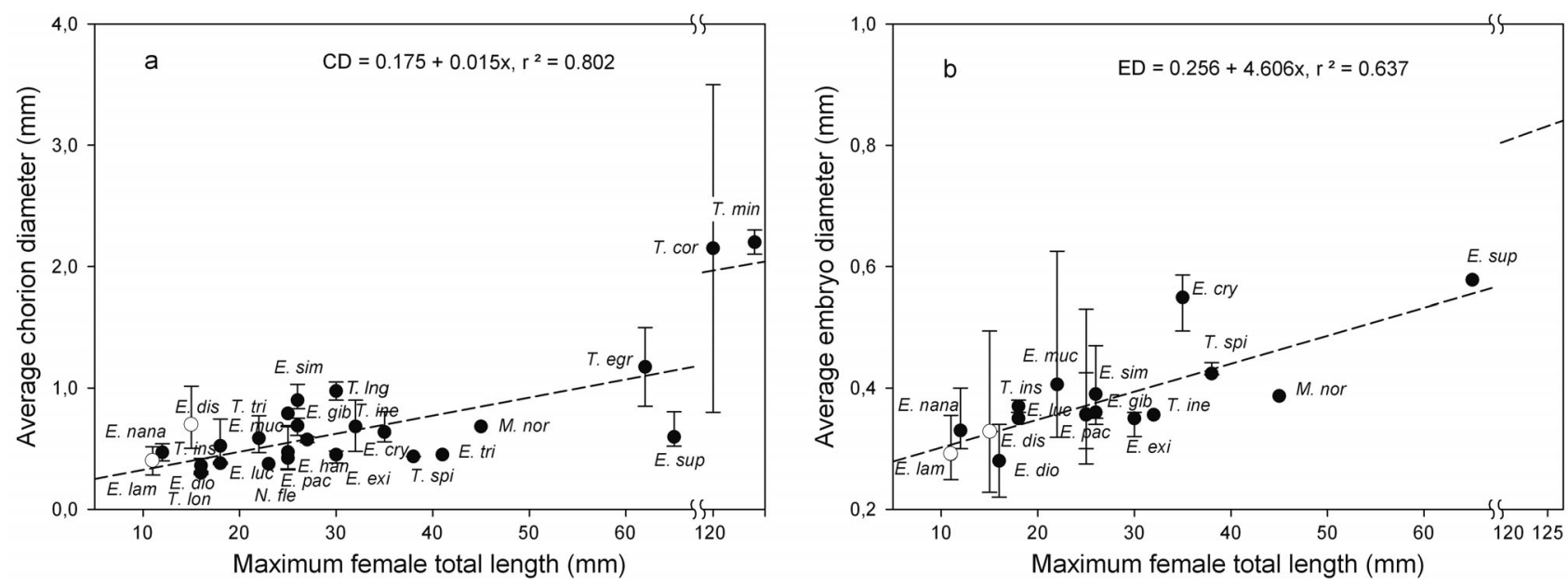

Fig. 7. Interspecific comparison of average female length (Baker et al. 1990) and average (a) chorion and (b) embryo diameter of Euphausia lamelligera and E. distinguenda (open circles) and 24 other broadcast spawning species (filled circles). Bars = min. and max. values recorded based on Mauchline (1988), Brinton et al. (2000), and Gómez-Gutiérrez et al. (2010a). Dashed line $=$ adjusted linear regression with equation shown. E. cry = Euphausia crystallorophias, E. dio $=E$. diomideae, E. dis $=E$. distinguenda, E. exi = E. eximia, E. gib =E. gibboides, E. han =E. hanseni, E. luc = E. lucens, E. lam = E. lamelligera, E. muc $=$ E. mucronata, E. nana = E. nana, E. sim =E. similis, E. sup = E. superba, E. tri = E. tricantha, M. nor = Meganyctiphanes norvegica, $N$. fle $=$ Nematobrachion flexipes, $T$. ine $=$ Thysanoessa inermis, $T$. ins $=$ Thysanoessa inspinata, T. lon $=T$ Thysanoessa longicaudata, $T$. lng = Thysanoessa longipes, $T$. ras = Thysanoessa raschi, $T$. spi $=$ Thysanoessa spinifera, $T$. cor $=$

Thysanopoda cornuta, T. egr = Thysanopoda egregia, T. min = Thysanopoda minyops, T. tri = Thysanopoda tricuspidata

tions of the MN stage are correct based on evidence from gravid females that spawned under laboratory conditions. Additionally, we provided morphological data on the previously unknown embryonic and early larval development (N1, N2, and PMN) stages. The embryology of both tropical species exhibited the same ontogeny as previously detailed morphological descriptions and cell maps known for several species with broadcast and sac-spawning reproductive strategies (Sars 1898, Taube 1909, 1915, George 1984, Gómez-Gutiérrez 2002, 2003, 2006, Alwes \& Scholtz 2004, Gómez-Gutiérrez et al. 2010a, MontuyGómez et al. 2012, Jia et al. 2014). However, E. distinguenda eggs had distinctive morphology, with the chorion diameter well above the theoretically expected size considering the female total length of this species $(<14.5 \mathrm{~mm})$, whereas the embryo diameter was near the predicted average (this means anomalously large PVS) (Gómez-Gutiérrez et al. 2010a, our Fig. 7). This morphological feature makes the identification of species from eggs collected directly from the water column in the northern ETP relatively easier.

A monthly time series (1996 to 1998) from the Mexican central Pacific $\left(19^{\circ} \mathrm{N}, 105^{\circ} \mathrm{W}\right)$ reported that of the total abundance of 8 krill species (larval and postlarval phases), E. distinguenda contributed between 88 and $90 \%$ (oceanic affinity), and E. lamelligera contributed $\sim 7 \%$ (neritic affinity) (Ambriz-Arreola et al. 2012). Thus, we expect that most of the eggs collected in this region should belong to these 2 numerically dominant species. The biometric measurements obtained in the present study will assist in the identification of E. lamelligera and E. distinguenda eggs obtained from field zooplankton collections in order to infer spatio-temporal distribution patterns - as in previous studies off the Oregon coast where spawning periods and cross-shelf distribution was defined for the 2 numerically dominant krill E. pacifica (oceanic affinity) and T. spinifera (neritic affinity) (Feinberg \& Peterson 2003, Gómez Gutiérrez et al. 2005, 2010a), and in the lower St. Lawrence Estuary with the spatio-temporal spawning patterns of Meganyctiphanes norvegica (Plourde et al. 2011).

Our study area is inhabited by 13 other tropical krill species that have low relative abundance $(<5 \%)$. From this $5 \%$, the most frequently sampled include 3 broadcast spawning species (E. eximia, E. diomedeae, and E. tenera) and 3 sac-spawning krill species (Nematoscelis gracilis, Stylocheiron affine, and S. carinatum) (Brinton 1979, Gómez-Gutiérrez \& Hernández-Trujillo 1994, Färber-Lorda et al. 2004, 2010, Ambriz-Arreola et al. 2012). The mean chorion and PVS measurements of eggs of E. eximia are known (but not for each development stage) and the nauplii were not drawn because they are similar to 
those observed to E. gibboides (Knight 1980). The early larval stages (N1 and N2) of both E. tenera and E. diomedeae remain undescribed, and intraspecific morphology should be compared in a future study.

A previous study reported that broadcast spawning krill species E. pacifica, T. spinifera, and T. inspinata can potentially employ 3 different hatching mechanisms: backward, forward, and flipping (GómezGutiérrez 2002). This author stated that the backward hatching of the N1 stage is the main hatching mechanism for these temperate species, and also demonstrated that it is strongly associated with higher hatching success in comparison to forward and flipping mechanisms. Our observations showed that E. lamelligera and E. distinguenda embryos hatched exclusively as N1 using the backward hatching mechanism. Delayed hatching is typically associated with low temperatures and lack of stimulus to break the chorion. This temperature dependent reproductive adaptation explains the high hatching success (average $90 \%$ ) observed in both tropical species, and their consecutive high numerical dominance with respect to the other 13 krill species that inhabit the northern region of the ETP (Brinton 1979, GómezGutiérrez \& Hernández-Trujillo 1994, Färber-Lorda et al. 2004, 2010, Ambriz-Arreola et al. 2012).

The PMN larval development stage was previously considered exclusive to the life cycle of sac-spawning krill species (Brinton et al. 2000). We clearly demonstrate that the PMN stage occurs in the life cycle of both E. lamelligera and E. distinguenda, albeit of relatively short duration, with evidence of PMN-MN exuvia release (see Fig. S2 in the Supplement). The morphology is similar to the PMN known for other sac-spawning krill species. This observational evidence indicates that species of sac-spawning and occasionally broadcast reproductive strategies develop through a PMN stage, contrary to the conceptualization that this stage is exclusive to sac-spawning euphausiid species. Knight $(1975,1980)$ did not find a PMN in the tropical broadcast spawning species $E$. eximia or E. gibboides during rearing experiments.

With respect to the MN stage, an intraspecific comparison evidenced notable differences in morphology among E. lamelligera and E. distinguenda and those of congeners of the genus Euphausia. E. eximia and E. diomedeae $\mathrm{MN}$ have a high dorsal crest with short and long spines, respectively, and the E. tenera MN possess 2 pairs of spines on the anterior margin of the carapace (Knight 1980, Brinton et al. 2000). In contrast, the $\mathrm{MN}$ of $E$. distinguenda we described has a slightly more marked dorsal keel than previously illustrated in Brinton et al. (2000) (Fig. 5). The MN stage of E. lamelligera and E. distinguenda has dorsal keels without spines and distinct spinal arrangements on the carapace (Fig. 5). The unique morphological characteristics in the MN stage of E. lamelligera and $E$. distinguenda observed in our study help to distinguish them from other Euphausia species that inhabit the ETP.

\section{Embryonic development rates of tropical krill species}

Our measurements of embryonic and early larval development times confirmed the expectation that higher temperatures in tropical habitats promote faster metabolic rates, resulting in shorter development times. We argue that E. lamelligera and $E$. distinguenda are not only among the smallest krill in the world, with the lowest brood sizes for broadcast spawning species, but also the species with the fastest development rates recorded so far in the Order Euphausiacea. Comparing embryonic development, hatching time, and early larval development time from spawning to $\mathrm{MN}$ stage for other species (Fig. 8), it is clear that polar and temperate broadcast spawning species have embryos and larvae with development times several times longer than species from tropical ecosystems like E. lamelligera and E. distinguenda. Both tropical species reached the $\mathrm{N} 1$ stage (12 $\mathrm{h}$ after hatching; Table 5) 8 and 12 times faster than the subtropical sacspawning species $N$. simplex (91 h after hatching; Gómez-Gutiérrez \& Robinson 2005), and Antarctic krill E. superba (144 h after hatching; Quetin \& Ross 1984). It is well known that embryonic and early larval development rates of Antarctic species E. superba (Ross et al. 1988, Yoshida et al. 2004), and temperate species E. pacifica and Thysanoessa inermis (Iguchi \& Ikeda 1994, Gómez-Gutiérrez 2002, Pinchuk \& Hopcroft 2006) are closely associated with temperature and food quality and quantity for females (that fuel oogenesis) and for larvae since exogenous feeding begins from calyptopis 1 . In fact, we observed that females spawned their eggs relatively quickly, mostly because of their relatively low brood sizes, completing their release of eggs 1 or 2 $\mathrm{h}$ after we started their incubations (with an approximate maximum spawning rate of 96 eggs in less than $1 \mathrm{~h}$ ). Overall, this total release of eggs was faster than the Antarctic krill E. superba, which spawns between 1400 and 4000 eggs over a period of up to $10 \mathrm{~h}$ (5 to 30 eggs $\mathrm{min}^{-1}$ ), suggesting that spawning in these 2 tropical species does not 


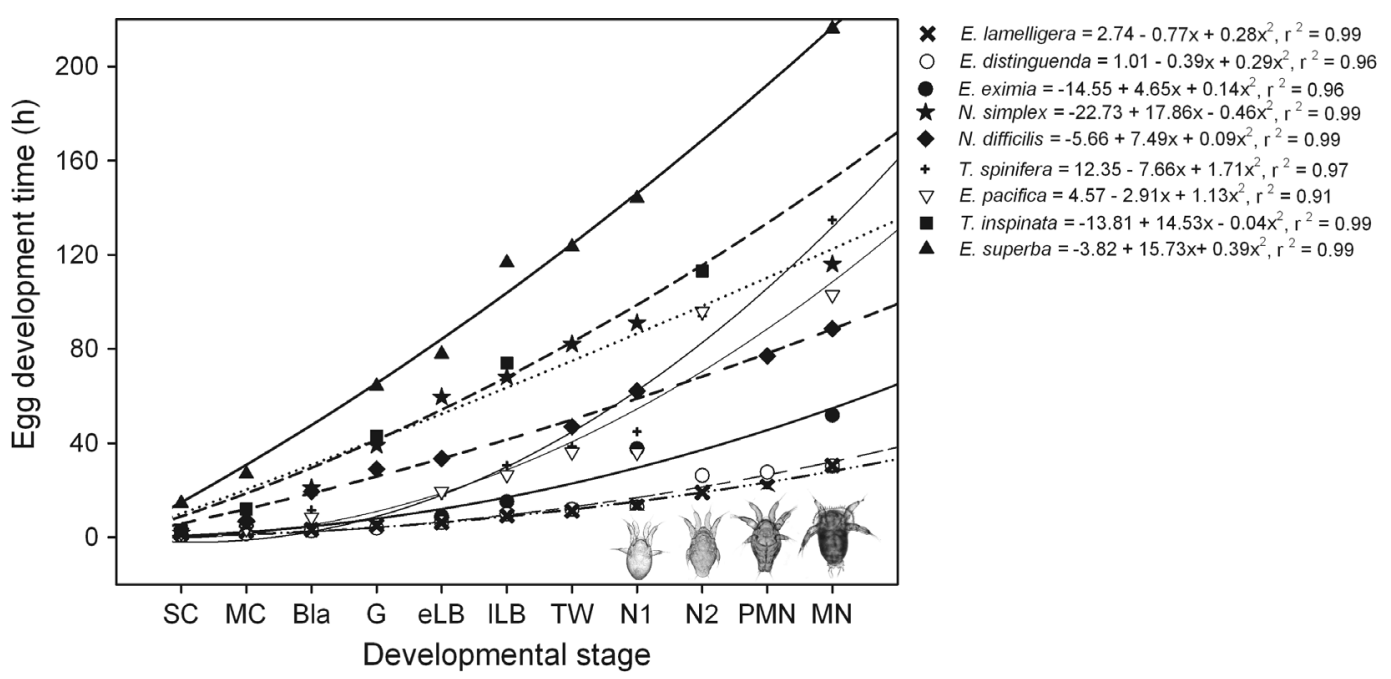

Fig. 8. Interspecific comparison of the embryonic and early larval development time of the tropical krill Euphausia lamelligera, E. distinguenda $\left(25 \pm 1^{\circ} \mathrm{C}\right.$; this study), and E. eximia $\left(18 \pm 1^{\circ} \mathrm{C} ;\right.$ Gómez-Gutiérrez unpubl. data), the subtropical species $N_{y C}-$ tiphanes simplex $\left(16 \pm 1^{\circ} \mathrm{C}\right.$; Gómez-Gutiérrez \& Robinson 2005), the temperate species Nematoscelis difficilis, Thysanoessa spinifera, T. inspinata, and E. pacifica $\left(10 \pm 1^{\circ} \mathrm{C} ;\right.$ Gómez-Gutiérrez 2002,2003$)$, and the Antarctic krill E. superba $\left(1 \pm 1^{\circ} \mathrm{C} ;\right.$ Quetin \& Ross $1984,0.5^{\circ} \mathrm{C}$ Jia et al. 2014). These incubation temperatures represent the mean temperature of the water column each krill species inhabits. Adjusted linear regression (second order polynomial fit) was calculated for each krill species. All regression lines are significant $(\mathrm{p}<0.05)$

modify female swimming behavior for very long, and therefore reduces vulnerability to predators (Tarling et al. 2009).

In conclusion, our study demonstrated that (1) the E. lamelligera and E. distinguenda populations exhibit continuous spawning patterns, but with a spawning maximum strongly associated with seasonal upwelling dynamics from the northern region of the ETP, as predicted by species inhabiting other tropical and temperate ecosystems (Pillar \& Stuart 1988, Ross \& Quetin 2000). (2) We established morphological and biometric features of diagnostic and taxonomic value to identify the eggs and early larval stages (N1, N2, PMN, and MN) of these 2 tropical species; this will allow identification of species collected from the field in order to infer preferences for spawning season and location, centers of larval dispersion, and clues about how embryos survive in the ocean. (3) The PMN stage is no longer thought to be exclusive for sacspawning species, giving the new perspective that some broadcast spawning species can develop through this larval stage. (4) The previous description of the MN stage of both species (Brinton et al. 2000) was morphologically and biometrically almost identical to that obtained under laboratory conditions. (5) Both $E$. lamelligera and E. distinguenda exhibit the fastest embryonic and early larval development rates (and likely female egg release due to their relatively small brood sizes) reported to date for any species of the
Order Euphausiacea. Finally, the scientific knowledge gained in the present study will help advance our rudimentary understanding of the reproductive biology/ecology of tropical krill, and represents a first step towards estimating krill secondary productivity in tropical regions that appear to be within the lower limit of temperate krill productivity from the Northern Eastern Pacific (Gómez-Gutiérrez et al. 2007).

Acknowledgements. We thank A. Alvizar-Martínez (Universidad de Guadalajara) for his invaluable technical help during field collection of live zooplankton at Jalisco coast throughout the entire study period, and A. Martínez-López (CICIMAR-IPN) for allowing us the use of the phytoplankton laboratory facilities to take photographs of larval stages' appendages. We also deeply thank 3 anonymous reviewers and editor Dr. Steffen Harzsch for comments that considerably improved an earlier version of the manuscript. Research funds were provided by University of Guadalajara. Consejo Nacional de Ciencia y Tecnología (CONACyT) supported I.A.-A. with a doctoral grant (2009-2013, No. 229198) and a post-doctoral fellowship (2014-2015, No. 224019). J.G.-G. and M.C.F.-G. are Sistema Nacional de Investigadores (SNI) fellows and J.G.-G. is EDI-IPN and COFAA-IPN fellow. I.A.A thanks the CICIMAR-IPN authorities and research staff for providing all resources and infrastructure necessary to write the manuscript, as part of his post-doctoral research stay. We dedicate this work to 2 landmark scientists who described euphausiid larvae and studied them from an ecological perspective all over the world: Edward Brinton (1924-2010) and Margaret D. Knight (1925-2014) (Scripps Institution of Oceanography). 


\section{LITERATURE CITED}

Alwes F, Scholtz G (2004) Cleavage and gastrulation of the euphausiacean Meganyctiphanes norvegica (Crustacea, Malacostraca). Zoomorphology 123:125-137

Ambriz-Arreola I, Gómez-Gutiérrez J, Franco-Gordo MC, Lavaniegos BE, Godínez-Domínguez E (2012) Influence of coastal upwelling-downwelling variability on tropical euphausiid abundance and community structure in the inshore Mexican central Pacific. Mar Ecol Prog Ser 451: 119-136

Baker A de C, Boden P, Brinton E (1990) A practical guide to the euphausiids of the world. Natural History Museum Publications, London

Brinton E (1962) The distribution of Pacific euphausiids. Bull Scripps Inst Oceanogr Univ Calif 8:51-270

Brinton E (1975) Euphausiids of Southeast Asian waters. Scientific results of marine investigations of the South China Sea and the Gulf of Thailand. Naga Report 4:1-287

Brinton E (1979) Parameters relating to the distribution of planktonic organisms, especially euphausiids in the Eastern Tropical Pacific. Prog Oceanogr 8:125-189

Brinton E, Townsend A (1980) Euphausiids in the Gulf of California - the 1957 cruises. Calif Coop Ocean Fish Invest Rep 21:211-236

Brinton E, Ohman MD, Townsend AW, Knight MD, Bridgeman AL (2000) Euphausiids of the world ocean. World Biodiversity Database CD-ROM Series, Expert Center for Taxonomic Identification, Amsterdam

Cepeda-Morales J, Beier E, Gaxiola-Castro G, Lavín MF, Godínez VM (2009) Effects of the oxygen minimum zone on the second chlorophyll maximum in the Eastern Tropical Pacific off Mexico. Cienc Mar 35:389-403

Färber-Lorda J, Lavin MF, Zapatero MA, Robles JM (1994) Distribution and abundance of euphausiids in the Gulf of Tehuantepec during wind forcing. Deep-Sea Res I 41: 359-367

Färber-Lorda J, Trasviña A, Cortés-Verdín P (2004) Trophic conditions and zooplankton distribution in the entrance of the Sea of Cortés during summer. Deep-Sea Res II 51: 615-627

Färber-Lorda J, Trasviña A, Cortés-Verdín P (2010) Summer distribution of euphausiids in the entrance of the Sea of Cortés in relation to hydrography. Deep-Sea Res II 57: 631-641

- Feinberg LR, Peterson WT (2003) Variability in duration and intensity of euphausiid spawning off central Oregon, 1996-2001. Prog Oceanogr 57:363-379

Feinberg LR, Shaw CT, Peterson WT (2007) Long-term laboratory observations of Euphausia pacifica fecundity: a comparison of two geographic regions. Mar Ecol Prog Ser 341:141-152

Feinberg LR, Shaw CT, Peterson WT, Decima M, Okazaki Y, Ju SJ (2013) Euphausia pacifica brood sizes: a North Pacific synthesis. J Plankton Res 35:1192-1206

> Fernández-Álamo MA, Färber-Lorda J (2006) Zooplankton and the oceanography of the Eastern Tropical Pacific: a review. Prog Oceanogr 69:318-359

George RY (1984) Ontogenic adaptations in growth and respiration of Euphausia superba in relation to temperature and pressure. J Crustac Biol 4:255-262

George RY, Strömberg JO (1985) Development of eggs of Antarctic krill Euphausia superba in relation to pressure. Polar Biol 4:125-133

Gómez-Gutiérrez J (2002) Hatching mechanism and delayed hatching of the eggs of three broadcast euphausiid species under laboratory conditions. J Plankton Res 24:1265-1276

> Gómez-Gutiérrez J (2003) Hatching mechanism and accelerated hatching of the eggs of a sac-spawning euphausiid Nematoscelis difficilis. J Plankton Res 25:1397-1411

Gómez-Gutiérrez J (2006) Hatching mechanisms and death of euphausiid embryos during hatching: Evidences for evolutionary reversal of the free-living nauplius? CICIMAR Oceánides 21:63-79

Gómez-Gutiérrez J, Hernández-Trujillo S (1994) Euphausiacea and Copepoda of the oceanic front off Cabo San Lucas BCS, Mexico in August of 1988. Rev Biol Trop 42: $155-164$

Gómez-Gutiérrez J, Robinson CJ (2005) Embryonic early larval development time, hatching mechanism and interbrood period of the sac-spawning euphausiid Nyctiphanes simplex Hansen. J Plankton Res 27:279-295

Gómez-Gutiérrez J, Peterson WT, Miller CB (2005) Crossshelf life-stage segregation and community structure of the euphausiids off central Oregon (1970-1972). DeepSea Res II 52:289-315

Gómez-Gutiérrez J, Feinberg LR, Shaw T, Peterson WT (2006) Variability of brood size and female length of Euphausia pacifica Hansen among three populations in the North Pacific. Mar Ecol Prog Ser 323:185-194

Gómez-Gutiérrez J, Feinberg LR, Shaw T, Peterson WT (2007) Interannual and geographical variability of the brood size of the euphausiids Euphausia pacifica and Thysanoessa spinifera along the Oregon coast (19992004). Deep-Sea Res I 54:2145-2169

> Gómez-Gutiérrez J, Peterson WT, Miller CB (2010a) Embryo biometry of three broadcast spawning euphausiid species applied to identify cross-shelf and seasonal spawning patterns along the Oregon coast. J Plankton Res 32: 739-760

> Gómez-Gutiérrez J, Rodríguez-Jaramillo C, Del ÁngelRodríguez J, Robinson CJ, Zavala-Hernández C, Tremblay N, Martínez-Gómez S (2010b) Biology of the subtropical sac-spawning euphausiid Nyctiphanes simplex in the northwestern seas of Mexico: interbrood period, gonad development and lipid content. Deep-Sea Res II 57:616-630

Gómez-Gutiérrez J, Martínez-Gómez S, Robinson CJ (2012) Seasonal growth, molt, and egg production of $\mathrm{NyC}$ tiphanes simplex (Crustacea: Euphausiacea) juveniles and adults in the Gulf of California. Mar Ecol Prog Ser 455:173-194

Iguchi N, Ikeda T (1994) Experimental study on brood size, egg hatchability and early development of a euphausiid Euphausia pacifica from Toyama Bay, southern Japan Sea. Bull Japan Sea Natl Fish Res Inst 44:49-57

Jia Z, Virtue P, Swadling KM, Kawaguchi S (2014) A photographic documentation of the development of Antarctic krill (Euphausia superba) from egg to early juvenile. Polar Biol 37:165-179

Knight MD (1975) The larval development of Pacific Euphausia gibboides (Euphausiacea). Fish Bull 73:145-168

Knight MD (1980) Larval development of Euphausia eximia (Crustacea: Euphausiacea) with notes on its vertical distribution and morphological divergence between populations. Fish Bull 78:313-335

Lavaniegos BE (1992) Growth and larval development of Nyctiphanes simplex in laboratory conditions. Calif Coop Ocean Fish Invest Rep 33:162-171 
Lavaniegos BE, Lara-Lara JR, Brinton E (1989) Effects of the 1982-83 El Niño event on the euphausiid populations of the Gulf of California. Calif Coop Ocean Fish Invest Rep 30:73-85

López-Sandoval DC, Lara-Lara JR, Álvarez-Borrego S (2009a) Phytoplankton production by remote sensing in the region off Cabo Corrientes, Mexico. Hidrobiológica 19:185-192

López-Sandoval DC, Lara-Lara JR, Lavín MF, Álvarez-Borrego S, Gaxiola-Castro G (2009b) Primary productivity observations in the Eastern Tropical Pacific off Cabo Corrientes, Mexico. Cienc Mar 35:169-182

Mathew KJ (1971) Studies on the larval stages of Euphausiacea from the Indian Seas. 1. Diagnostic characters of post-naupliar stages of Euphausia diomedeae Ortmann and E. distinguenda Hansen. J Mar Biol Assoc India 13: $52-60$

Mathew KJ (1975) Studies on the larval history of two species of Euphausiacea from the Indian Seas. J Mar Biol Assoc India 17:1-16

Mathew KJ (1980) The egg potential in two species of Euphausiacea (Crustacea) of the Southeastern Arabian Sea. J Mar Biol Assoc India 22:85-88

Mauchline J (1988) Egg and brood sizes of oceanic pelagic crustaceans. Mar Ecol Prog Ser 43:251-258

Montuy-Gómez D, Gómez-Gutiérrez J, Rodríguez-Jaramillo C, Robinson CJ (2012) Nyctiphanes simplex (Crustacea: Euphausiacea) temporal association of embryogenesis and early larval development with female molt and ovarian cycles. J Plankton Res 34:531-547

Mundhenke DJ (1969) The relationships between water masses and euphausiids in the Gulf of California and the Eastern Tropical Pacific. PhD thesis, Naval Postgraduate School, Monterey, CA

Nicol S, De La Mare W, Stolp M (1995) The energetic cost of egg production in the Antarctic krill (Euphausia superba Dana). Antarct Sci 7:25-30

Pillar SC, Stuart V (1988) Population structure, reproductive biology and maintenance of Euphausia lucens in the southern Benguela Current. J Plankton Res 10:1083-1098

Pinchuk AI, Hopcroft RR (2006) Egg production and early development of Thysanoessa inermis and Euphausia pacifica (Crustacea: Euphausiacea) in the northern Gulf of Alaska. J Exp Mar Biol Ecol 332:206-215

Plourde S, Winkler G, Joly P, St-Pierre JF, Starr M (2011) Long-term seasonal and interannual variations of krill spawning in the lower St Lawrence estuary, Canada, 1979-2009. J Plankton Res 33:703-714

Ponomareva LA (1963) The euphausiids of the North Pacific, their distribution and ecology. Dokl Akad Nauk SSSR, Moscow (English translation, Israel Program for Scientific Translations, Jerusalem, 1966)

Editorial responsibility: Steffen Harzsch, Greifswald, Germany
Ponomareva LA (1969) Investigations on some tropical euphausiid species of the Indian Ocean. Mar Biol 3: 81-86

> Quetin LB, Ross RM (1984) Depth distribution of developing Euphausia superba embryos, predicted from egg sinking rates. Mar Biol 79:47-53

> Quetin LB, Ross RM (1989) Effects of oxygen, temperature and age on the metabolic rate of the embryos and early larval stage of the Antarctic krill Euphausia superba Dana. J Exp Mar Biol Ecol 125:43-62

Ross R, Quetin L (2000) Reproduction in Euphausiacea. In: Everson I (ed) Krill: biology, ecology and fisheries. Blackwell Science, Oxford, p 150-181

Ross RM, Quetin LB, Kirsch E (1988) Effect of temperature on development times and survival of early larval stages of Euphausia superba. J Exp Mar Biol Ecol 121:55-71

Sars GO (1898) On the propagation and early development of Euphausiidae. Arch Math Naturv 20:1-41

Stuart V (1992) Fecundity of Euphausia lucens (Hansen) laboratory evidence of multiple broods. J Exp Mar Biol Ecol 160:221-228

> Tarling GA, Cuzing-Roudy J, Whooton K, Johnson ML (2009) Egg release behavior in Antarctic krill. Polar Biol 32:1187-1194

Taube E (1909) Beiträge zur Entwicklungsgeschichte der Euphausiden. I. Die Furchung des Eis bis zur Gastrulation. Z Wiss Zool 92:427-464

Taube E (1915) Beiträge zur Entwicklungsgeschichte der Euphausiden. II. Von der Gastrulation bis zum Furciliastadium. Z Wiss Zool 94:577-658

Timofeev SF, Sklyar VV, Savinov MV (2004) Stabilizing selection on egg size in the euphausiid, Thysanoessa raschii (M. Sars, 1864) (Euphausiacea) in the Barents Sea. Crustac Int J Crustac Res 77:265-276

> Valentine JW, Ayala FJ (1976) Genetic variability in krill. Proc Natl Acad Sci USA 73:658-660

Wang R (1965) On the larval stages of Pseudeuphausia sinica Wang and Chen (Euphausiacea). Oceanol Limnol Sin 7:35-53

Wilson S, Meekan M, Carleton J, Stewart T, Knott B (2003) Distribution, abundance and reproductive biology of Pseudeuphausia latifrons and other euphausiids on the southern North West Shelf, Western Australia. Mar Biol 142:369-379

Yoshida T, Toda T, Hirano Y, Matsuda T, Kawaguchi S (2004) Effect of temperature on embryo development time and hatching success of the Antarctic krill Euphausia superba Dana in the laboratory. Mar Freshw Behav Physiol 37:137-145

Zar J (1996) Biostatistical analysis, 3rd edn. Prentice Hall, Upper Saddle River, NJ

Submitted: October 22, 2014; Accepted: May 28, 2015 Proofs received from author(s): June 15, 2015 